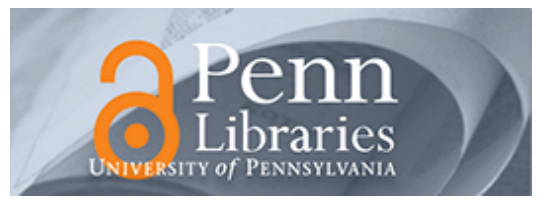

University of Pennsylvania

ScholarlyCommons

Real Estate Papers

Wharton Faculty Research

$9-2003$

\title{
Network Effects, Congestion Externalities, and Air Traffic Delays: Or Why Not All Delays Are Evil
}

Christopher Mayer

University of Pennsylvania

Todd Sinai

University of Pennsylvania

Follow this and additional works at: https://repository.upenn.edu/real-estate_papers

Part of the Management and Operations Commons, and the Real Estate Commons

\section{Recommended Citation}

Mayer, C., \& Sinai, T. (2003). Network Effects, Congestion Externalities, and Air Traffic Delays: Or Why Not All Delays Are Evil. American Economic Review, 93 (4), 1194-1215. http://dx.doi.org/10.1257/

000282803769206269

This paper is posted at ScholarlyCommons. https://repository.upenn.edu/real-estate_papers/80

For more information, please contact repository@pobox.upenn.edu. 


\title{
Network Effects, Congestion Externalities, and Air Traffic Delays: Or Why Not All Delays Are Evil
}

\author{
Abstract \\ We examine two factors that explain air traffic congestion: network benefits due to hubbing and \\ congestion externalities. While both factors impact congestion, we find that the hubbing effect dominates \\ empirically. Hub carriers incur most of the additional travel time from hubbing, primarily because they \\ cluster their flights in short time spans to provide passengers as many potential connections as possible \\ with a minimum of waiting time. Non-hub flights at the same hub airports operate with minimal additional \\ travel time. These results suggest that an optimal congestion tax might have a relatively small impact on \\ flight patterns at hub airports. \\ Disciplines \\ Aviation | Management and Operations | Real Estate
}




\title{
Network Effects, Congestion Externalities, and Air Traffic Delays: Or Why Not All Delays Are Evil
}

\author{
By Christopher Mayer and Todd SinaI*
}

\begin{abstract}
We examine two factors that explain air traffic congestion: network benefits due to hubbing and congestion externalities. While both factors impact congestion, we find that the hubbing effect dominates empirically. Hub carriers incur most of the additional travel time from hubbing, primarily because they cluster their flights in short time spans to provide passengers as many potential connections as possible with a minimum of waiting time. Non-hub flights at the same hub airports operate with minimal additional travel time. These results suggest that an optimal congestion tax might have a relatively small impact on flight patterns at hub airports. (JEL L2, L5, L9, D6)
\end{abstract}

Over the last few years, air traffic delays have garnered increasing attention. The year 2000 produced record delays with more than onequarter of all flights arriving at least 15 minutes behind schedule. With infrastructure improvements being years away and conventional wisdom holding that delays are caused by congestion externalities, proposed policy remedies have focused on economic solutions such as congestion pricing. However, selecting the appropriate remedy depends crucially on what is causing congestion and delays. In this paper, we try to determine the economic underpinnings of air traffic congestion.

\footnotetext{
* Mayer: The Wharton School, 314 Lauder-Fischer Hall, University of Pennsylvania, 256 South 37th Street, Philadelphia, PA 19104 (e-mail: mayerc@wharton.upenn.edu); Sinai: The Wharton School, 308 Lauder-Fischer Hall, University of Pennsylvania, 256 South 37th Street, Philadelphia, PA 19104, and National Bureau of Economic Research (e-mail: sinai@wharton.upenn.edu). We are especially indebted to Jeff Butler of the U.S. Department of Transportation for providing the flight data used in this paper. We also wish to thank two anonymous referees, Betsy Bailey, Judy Chevalier, Glenn Ellison, David Genesove, Ed Glaeser, Richard Golaszewski, Joseph Gyourko, Dorothy Robyn, Andrew Samwick, Joel Waldfogel, Clifford Winston, and seminar participants at Cornell University, Dartmouth College, Harvard University, MIT, NBER, University of British Columbia, University of Chicago, University of Pennsylvania, and Yale University for helpful comments. This material is based upon work supported by the National Science Foundation under Grant No. 0214410 and the Zell/ Lurie Real Estate Center at The Wharton School. The excellent research assistance of Sam Chandan, James Knight-Dominick, and Dou-Yan Yang is appreciated.
}

One potential cause of greater travel times is the classic congestion externality, also known as the "tragedy of the commons." According to this hypothesis, congestion occurs because most airports allow unlimited landings and takeoffs and airlines schedule flights without valuing the fact that their traffic will increase travel time for other airlines. ${ }^{1}$ Failure to internalize the true marginal cost of adding a flight leads to congestion at airports and flights being delayed. The standard solutions are to use a Pigouvian tax, such as pricing by time of day or the length of a queue, or to restrict traffic and assign property rights by selling ownership of scarce landing slots at congested airports. Previous empirical research has focused on these solutions, suggesting that a congestion tax would have substantial efficiency gains in reducing the level of delays [Alan Carlin and R. E. Park (1970); Steven Morrison and Clifford Winston (1989); Joseph I. Daniel (1995); Daniel and Munish Pahwa (2000)].

One problem with the congestion externality explanation for delays, however, is that it is not consistent with the delay pattern across all U.S. airports. In the "tragedy of the commons," it is usually assumed that there are multiple agents who do not take into account the externality that they create for others. While congestion externalities might explain why airports without a

\footnotetext{
${ }^{1}$ See models in William S. Vickrey (1969) and Richard Arnott (1979) as examples of transport systems with inefficient congestion.
} 
single dominant carrier, such as LaGuardia, Los Angeles, JFK, or Boston, should have high delays, this model may not explain why airports that are dominated by one large carrier, such as Philadelphia, Newark, Atlanta, or Detroit, are consistently among the airports with the largest overall delays. $^{2}$

We propose a second explanation for high air traffic delays: the network benefits associated with the hub and spoke system. ${ }^{3}$ Just one new round-trip flight from a hub where an airline already connects to $N$ cities will create $2 N$ additional connecting routes. Since the number of potential connections grows exponentially in the number of markets served by the hub carrier, as long as demand for air travel in potential new markets is not diminishing faster than the increasing benefits of the larger network, a hub carrier has an incentive to serve an ever greater number of markets. These increasing returns to scale are offset by the limited flight capacities of airports, so a hub airline must trade off the higher benefits of serving additional markets against rising marginal congestion costs due to more traffic, such as longer connecting times and greater delays. According to this simple model, longer delays at hub airports are the equilibrium outcome of a hub airline equating high marginal benefits from hubbing with the marginal cost of delays.

At a typical airport, hub airlines want to maximize the number of possible connecting markets for passengers, but also want to minimize passenger travel time spent on congestion delays or waiting for flight connections. To solve this problem, hub carriers often choose to cluster their flights at periodically spaced "hubbing times" to create the greatest variety of passenger destinations but these convenient connections come at the cost of higher congestion. Hub carriers can partially offset the increased congestion by smoothing scheduled

\footnotetext{
${ }^{2}$ Jan K. Brueckner (2002) shows that a single dominant carrier will internalize much of the externality that would otherwise lead to greater delays. The paper demonstrates that with one or more large carriers at an airport the optimal congestion tax is a decreasing function of the market share of the dominant carrier(s).

${ }^{3}$ See Nicholas Economides (1996) for a general explanation of the economics of networks and Garth Saloner and Andrea Shepard (1995) for an example of empirical evidence in favor of internalized network benefits in the adoption of ATMs.
}

flight arrival times, albeit by increasing the length of connections for some passengers. Non-hub carriers, who do not obtain network benefits, have no incentive to cluster flights at the same peak hubbing times and thus will incur fewer delays than the hub carrier. ${ }^{4}$

We examine these hypotheses using U.S. Department of Transportation data on flights from 1988-2000 by all major air carriers with more than a 1-percent U.S. market share, over 66 million flights in total covering more than 250 airports. Our primary measure of congestion delay is the increase in travel time relative to the minimum feasible time on a route. On average, a flight originating at a hub airport requires up to 7.2 minutes longer to travel to its destination than a flight originating at a non-hub airport. Planes flying to a hub airport take up to 4.5 more minutes, on average. Delays at hub airports are increasing in the size of the hub, defined as the number of markets served by the hub carrier. However, the hub carrier itself bears most of the increase in travel time associated with hubs. In all cases, hubbing-related delays are significantly larger for flights departing from a hub than for arriving flights.

The increase in delays associated with hubbing is partially offset by reduced congestion externalities at airports where the hub carrier has a dominant market share. However, the empirical impact of airport concentration (HerfindahlHirschman Index $[\mathrm{HHI}]$ ), which we use as a proxy for the extent to which delay costs are internalized by the carriers at the airport, is much more modest than for hubbing. A 20percentage-point increase in airport concentration leads to a 0.3 - to 1.4-minute decrease in travel time for all flights at the airport, depending on whether or not we include airport fixed effects. This effect is similar for both arriving and departing flights.

After 1995, we have more detailed data on travel times and are able to decompose the source of delays. All of the additional travel time due to originating at a hub is spent waiting

\footnotetext{
${ }^{4}$ Daniel (1995), David Encaoua et al. (1996), and Severin Borenstein and Janet Netz (1999) come to a different conclusion, suggesting that demand peaks and competition between carriers drives hub and non-hub airlines to cluster their flights at the same departure times. None of these papers incorporates the impact of network effects on scheduling decisions.
} 
at the gate or in line on a taxiway waiting to take off. If the destination airport is the airline's hub, some of the excess travel time occurs in the air, but the bulk of the additional delay comes from taxiing to the gate or waiting for a gate to become available. In addition, we can reject the hypothesis that hub carrier delays are the result of cascading delays due to late arriving aircraft on the previous inbound flight.

Alternative views of hub and spoke economics typically emphasize market power or economies of scale rather than the network effects we find. Previous empirical work has shown that hubbing gives the dominant hub carrier significant market power on nonstop flights to and from the hub airport. ${ }^{5}$ Some papers attribute the market power associated with hubs to barriers to entry imposed by a dominant airline, such as frequent flyer programs or computer reservation systems. Others argue that airlines benefit from economies of density, so that marginal costs decrease with number of markets served and the scale of service on those routes [Douglas Caves et al. (1984); Brueckner et al. (1992); Brueckner and Pablo T. Spiller (1994)]. Hubs may also increase the economic efficiency of an airline's operations [Scott McShan and Robert Windle (1989); Ken Hendricks et al. (1995, 1997); Brueckner and Yimin Zhang (2001)]. While market power and cost efficiencies are important factors in hub and spoke networks and could explain some delays at hub airports, neither explains why, in the absence of increasing returns to network connections, the hub carrier would accept high delays on its own hub flights relative to non-hub carrier flights to or from the same airport. ${ }^{6}$

\footnotetext{
${ }^{5}$ See Borenstein $(1989,1990,1991,1992)$, Alfred Kahn (1993), E. Han Kim and Vijay Singal (1993), Borenstein and Nancy Rose (1994), Singal (1996), Anming Zhang (1996), and Matthew Hergott (1997) for a discussion of the impact of hubs and having a dominant carrier at an airport on fares.

${ }^{6}$ While large enough declines in average cost with additional markets would generate a positive correlation between markets served and willingness to accept delays, it is inconsistent with hub carriers choosing to concentrate their flights at hubbing times. A carrier that was concerned with gaining low costs associated with serving additional cities, but was not interested in network benefits from connections, would evenly space its flights over the day to reduce congestion costs. Monopoly power raises the benefits of serving all cities, but the marginal benefit of serving any additional city still declines without considering network benefits.
}

The next section discusses the impact of network benefits and congestion externalities on the scheduling decisions of a hub and non-hub carrier and the resulting impact on air traffic delays. Section II describes the data and our measure of congestion delay. Section III presents the empirical specification and results and Section IV concludes with a policy discussion and an agenda of future research.

\section{Hubbing, Network Benefits, and Flight Delays}

In this section, we describe how network benefits and congestion externalities lead to greater delays. ${ }^{7}$ We also present a series of graphs of scheduled flights at the Dallas-Fort Worth and Boston airports as an example of scheduling practices by hub and non-hub carriers. In the end, we will be left with four basic empirical predictions. First, hub airports should be more congested than non-hub airports since hub airlines receive large network benefits from additional flights and thus are willing to accept greater marginal delay costs. Second, the bulk of the delays at hub airports should be borne by hub airlines' flights. Third, hub airlines could have greater delays for departures than arrivals. Finally, an airline's failure to internalize the delays caused to other airlines' flights will typically lead to overscheduling at the airport.

A non-hub carrier makes a straightforward profit-maximizing calculation when considering how to schedule flights at a given airport. The airline obtains revenue from offering point-topoint service between the airport and other cities, where that revenue is net of costs such as fuel, labor, and the rental costs of aircraft. On the cost side, congestion at an airport causes passengers to endure longer travel times, reducing their willingness to pay for a ticket, and increases an airline's operating costs such as fuel and labor. Thus a non-hub carrier trades off the marginal benefit of adding a flight to a new destination against the congestion cost of that flight, plus the cost of additional congestion that flight would impose on the non-hub carrier's other flights. Assuming that the non-hub carrier chooses to serve the highest value cities first,

\footnotetext{
${ }^{7}$ A working paper version of this article showed how these results could be obtained in a more formal model. That version is available from the authors upon request.
} 
the non-hub carrier will typically face decreasing returns in adding flights to more cities.

A hub carrier obtains the same direct benefits and costs as the non-hub airline, but it also gains additional revenue by serving connecting passengers. If the hub airline already connects to $N$ cities, it serves $N^{2}$ routes. Assuming uniform demand across cities, each additional city served increases revenue by $2 N$. That is, passengers in the new city will have $N$ new destinations, while passengers in each of the $N$ existing cities will have one more possible destination. The additional revenue can either come from higher load factors from connecting passengers or from higher fares due to offering travelers from outlying airports a greater variety of destinations. Even without identical cities, as long as the demand for travel to and from the next best city does not decline more than the increase in network benefits from serving a greater variety of destinations, the hub carrier will still face increasing returns to scale in serving additional markets. As before, the hub carrier will trade off the benefits of additional flights against the congestion costs faced by the additional flights themselves plus the increase in congestion imposed on the hub carrier's other flights.

It immediately follows that hub airports will have more traffic and greater delays than nonhub airports of equivalent size and with equal local demand. Since a hub carrier benefits from increasing returns associated with hubbing, in equilibrium the hub carrier has a greater value from adding more flights, or equivalently destinations, than a non-hub carrier and thus will accept greater congestion costs. In addition, as demand for air travel increases in the cities surrounding the hub, the value of point-to-point and connecting service will rise, leading to a greater equilibrium number of hub flights and thus even more congestion.

In addition to selecting the total number of flights, a hub airline must also decide how to schedule its flights over the day. Since the hub airline obtains increasing returns to scale only to the extent that passengers can feasibly connect between flights, the typical hub operates by scheduling flights to arrive, allowing passengers to deplane and board new aircraft, and then having those flights depart. Since passengers prefer shorter connections, longer connection times reduce the fares an airline can collect. Therefore, a hub airline would like to schedule its arrivals and departures as close together as possible, subject to the constraint that passengers have adequate time to make their connections. However, airports can support only a limited volume of takeoffs and landings, so planning more flights or scheduling them closer together increases congestion. In contrast, nonhub airlines obtain all of their revenue from point-to-point service so they have no benefit from bunching flights together.

As long as the marginal benefit from reducing connection times outweighs the additional congestion cost, hub airlines will cluster their flights close together in time, leading to a pattern of peak loading at a hub airport. In between these peaks are periods of inactivity while a hub carrier's planes are all in the air. As an alternative, the hub carrier could schedule some flights outside the hubbing peak. The demand for point-to-point service on those flights would be unaffected, but the network benefits would be lower than if they were scheduled during the hubbing time. Passengers would be less willing to connect from them to flights during the hubbing time or vice versa, reducing demand for all the hub airline's flights. Whether smoothing peak traffic makes economic sense depends on the reduction in the value of network benefits that comes from passengers discounting longer connections. If passengers place a high premium on short connections, it is profitable for the hub carrier to cluster flights together despite higher congestion costs.

This intuition is highlighted by considering the extreme case where a hub airline minimizes congestion costs by scheduling a uniform number of arrivals and departures throughout the day. That strategy produces the longest connection times, reducing the value of every potential destination, akin to providing fewer usable connections than are actually scheduled. Since the value of hubbing increases with the square of the number of potential destinations, a reduction in the effective size of the network can be very costly. Thus, the hub carrier may choose to cluster flights closer together even at the cost of higher congestion.

This pattern of hub airport scheduling leads to two empirical predictions. First, congestion at a hub should be increasing in the size of the hubbing peaks. These peaks reflect demand for connecting at the hub, so the size of the peaks can be measured by the number of potential destinations served by the hub carrier at the airport. Second, 
delays should mainly accrue to the hub carrier since non-hub carriers have no reason to cluster flights, let alone during the congested periods. Given this fact, most hub flights take place during congested hubbing times while only a small portion of non-hub flights do. Indeed, in our data non-hub carriers appear to operate atomistically, choosing a relatively constant, nonzero number of flights during most periods. The correlation between the density of hub and non-hub flights at hub airports is slightly negative $(-0.05)$ when the hub is operating. ${ }^{8}$ Thus the average hub airline flight would be more likely to face congestion than a non-hub flight.

Of additional interest, although not immediately obvious at first, is the empirical prediction that the hub airline will often choose to cluster departures more than arrivals. To see this, suppose that the hub carrier scheduled all its arrivals at one point in time and all the departures shortly thereafter. This approach eliminates costly long connections for passengers but also maximizes congestion. It pays for the airline to smooth some arrivals earlier as long as the reduction in congestion from shifting an arrival a bit earlier outweighs the lost revenue from the longer connections for some passengers. The hub airline will not typically choose to smooth both arrivals and departures since then some connections-from the earliest arrivals to the latest departures-would be excessively long and consumers would not want to book them. Yet why smooth arrivals instead of departures? The answer lies in the stochastic nature of flight operations. Airlines know that some flights will arrive late to the hub, but on a given day do not know which ones will be late. By clustering departures, airlines give themselves the option to depart whichever aircraft arrive first. The data below strongly support the prediction that departure delays at a hub are larger than arrival delays.

\footnotetext{
${ }^{8}$ While one might expect that non-hub carriers might prefer to operate more flights in less congested periods, in reality, the non-hub carrier faces a variety of networkrelated constraints that limit its flexibility in choosing flight times. For example, most non-hub carriers are operating flights to their own hubs, so they might face high costs of moving a flight to a different period. Also, the non-hub carrier's aircraft might be forced to incur additional time on the ground to wait for an uncongested period, which would also be costly. This finding is consistent with Daniel (1995), who also fails to reject atomistic behavior by non-hub carriers at Minneapolis airport.
}

Finally, less concentrated airports will have more delays. In our model, an airline-hub or non-hub-with a low market share will schedule more flights since less of the increase in average delay due to an additional flight accrues to their own aircraft. In other words, an airline imposes a delay externality on other carriers scheduled to fly around the same time. As the airline's share of flights increases, it internalizes more of the increase in average delay from each additional destination it schedules.

Explicitly recognizing that network benefits lead hub carriers to schedule more flights and bunch them together generates empirical predictions that differ from previous research. For example, Daniel (1995) assumes that the hub airline operates at exogenously determined peak times. Around those peak times, the hub carrier clusters its flights to minimize the cost of connections and schedules longer time between arrivals and departures to reduce the likelihood of missed connections. However, non-hub airlines in his model also prefer to fly during the same peaks. Competition to operate in peak periods limits the extent to which a hub airline can smooth the peaks to reduce congestion costs because any reduction of the number of its own flights at the peak will be partly or fully offset by entry of flights by the competitive fringe of non-hub carriers. Daniel concludes that optimal congestion pricing would increase social welfare by encouraging all airlines to smooth their arrival and departure traffic at peak times, reducing congestion. ${ }^{9}$ In contrast, by explicitly considering network benefits, our framework predicts that only the hub airline gains enough of an economic benefit from clustering its flights to put up with the resulting congestion delays. Thus hub carriers should face substantially higher congestion than non-hub carriers operating at the same airport. Since in our framework there is less of a congestion externality, the social welfare cost of delays is lower than in Daniel. Also, our framework explains the asymmetry between hub arrival and departure congestion.

\footnotetext{
${ }^{9}$ Daniel creates an extensive simulation model using data from a week of flights at Minneapolis-St. Paul airport (MSP), combining queuing theory with stochastic, timevarying arrival rates, endogenous scheduling decisions, and a bottleneck model to determine how air carriers should schedule flights within a peak.
} 


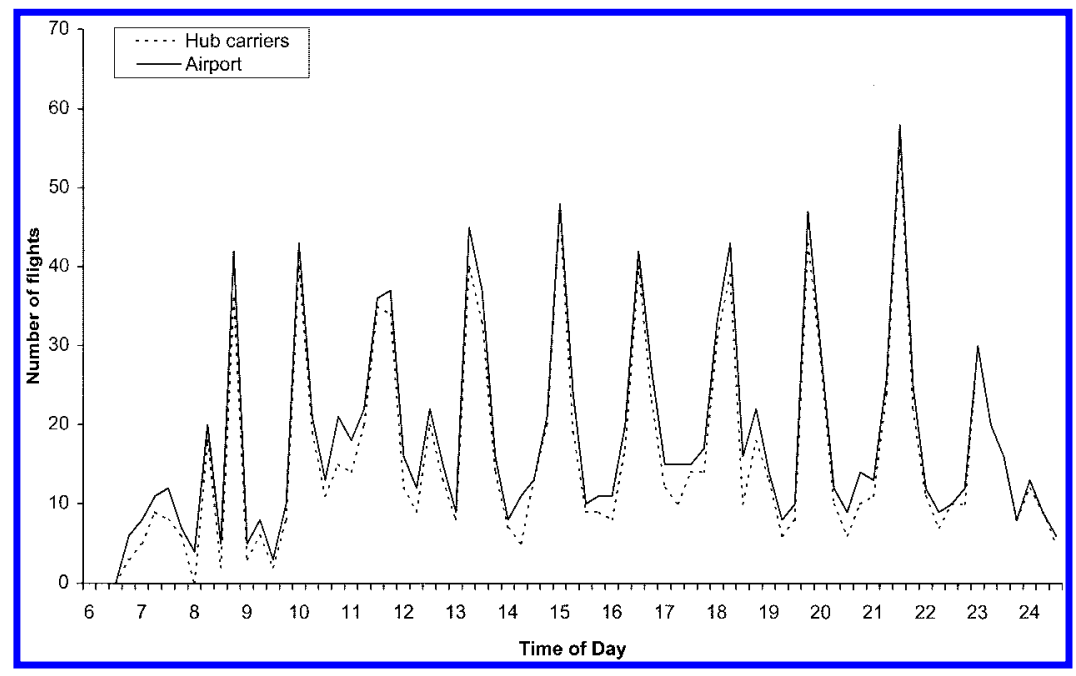

Figure 1. Hub Versus Airport's Total Flights at Dallas-Fort Worth (DFW)

In our analysis, we have assumed that airport capacity is fixed over time. However, some airports may have been able to make more efficient use of their runways by adding taxiways. Hub airports, which have peakier demand, might be less willing to invest in additional taxiway capacity than non-hub airports with smoother demand. ${ }^{10}$ If the hubbing-driven traffic pattern makes it financially infeasible for hub airports to increase their capacity to accommodate peak congestion, this is an additional mechanism through which hub airports might have higher delays. Nonetheless, differences in capacity expansion between hub and non-hub airports is unlikely to explain the findings that hub airlines incur a disproportionate share of congestion at hub airports, or that there are asymmetries between arrival and departure congestion at hubs.

The major predictions of the model are apparent when one looks at the flight schedule from Dallas-Fort Worth (DFW) airport. Figure 1 plots scheduled flights by hub and non-hub carriers at 15-minute intervals from 6 A.M. to midnight for an arbitrary date, Friday, October

\footnotetext{
${ }^{10}$ Although hub airports face different trade-offs from spoke airports regarding investments in capacity improvements, these trade-offs could go in either direction. On one hand, additional capacity at hubs will only be utilized during peak periods rather than throughout the day at a highdemand airport such as LaGuardia or Boston. However, the value of the extra capacity might be higher at hubs during the peak periods.
}

20, 2000. DFW has two hub carriers, American and Delta, although American operates the bulk of the flights at the airport. DFW is among the most congested airports in the country. Two facts are immediately apparent from this figure: (1) flights are clustered into peaks, and (2) most of the clustering is due to the hub carriers who bunch their flights together. In addition, Figure 2 shows that the hub carriers at DFW smooth their arrivals much more than departures.

This pattern of clustering flights is not evident at non-hub airports. For comparison, Figure 3 plots total flights at Boston Logan Airport (BOS) on the same date. While Delta and US Airways have fairly large market shares at BOS, neither operates a hub at the airport. Total flights at BOS have many more small ups and downs than at DFW, but DFW flights exhibit much more pronounced peak to trough variability than at BOS.

Clustering by the hub carrier leads to peak flight loads at the airport and delays around hubbing times since non-hub carriers do not fully offset the hub's spikes in flight volume. Figure 4 plots the total density of flights for hub and non-hub carriers at DFW. While non-hub carriers choose relatively smooth flight levels throughout the day, hub carriers bunch their flights into peaks that are much more pronounced and involve a much larger number of flights. We explore these hypotheses further in the empirical work that follows. 


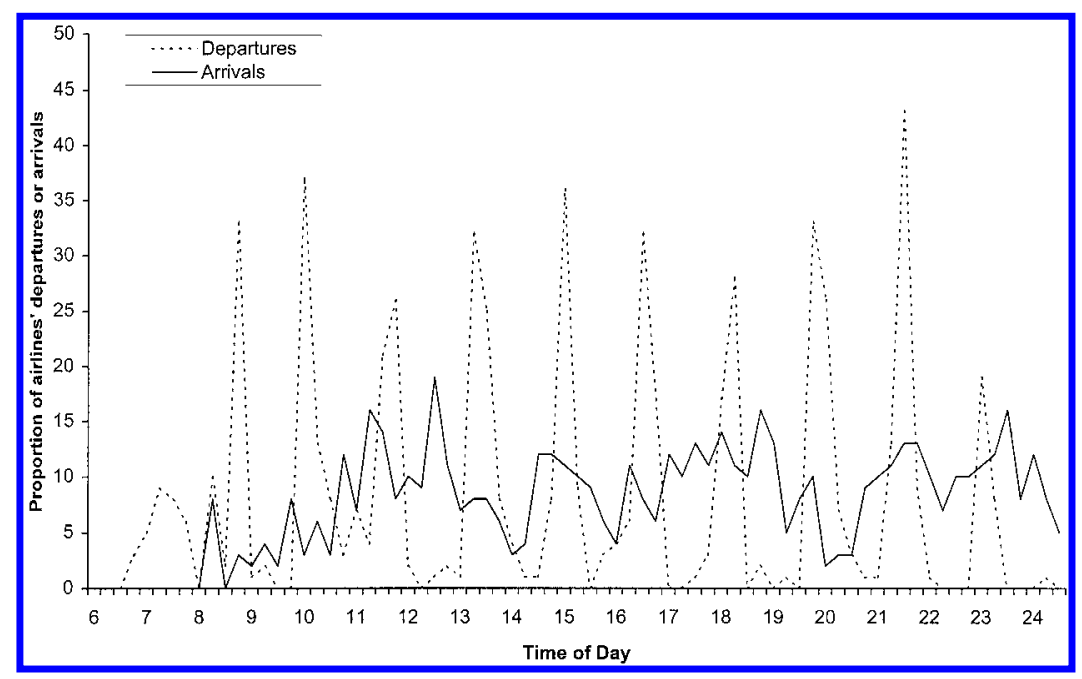

Figure 2. Hub Carriers' Departures and Arrivals at Dallas-Fort Worth (DFW)

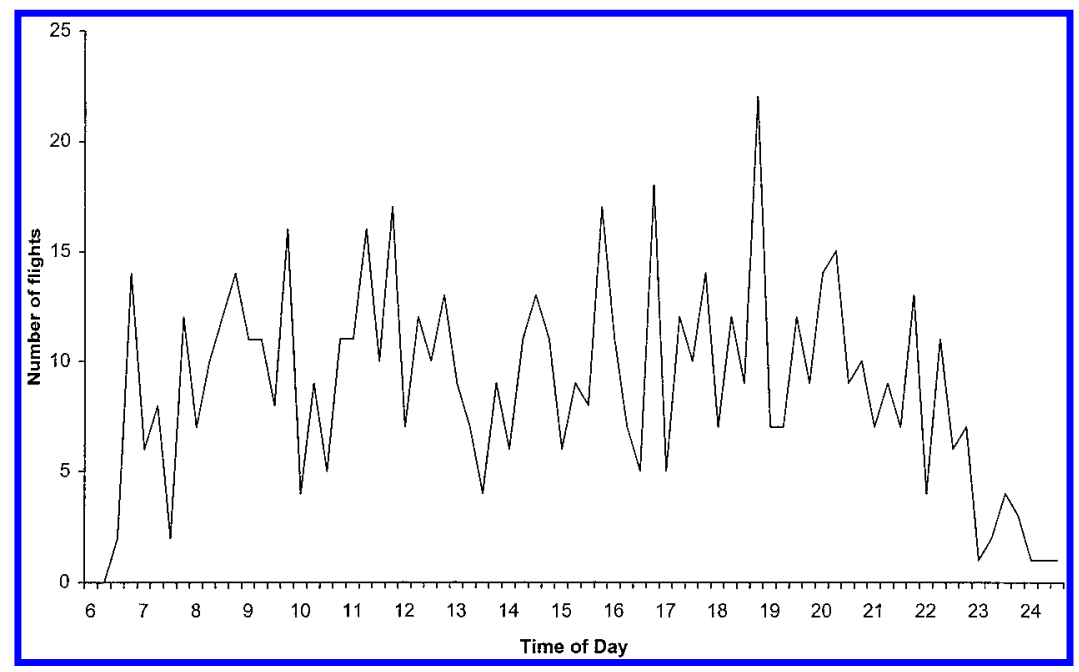

Figure 3. Total Flights at Boston Logan Airport (BOS)

\section{Data}

In 1988, the U.S. Department of Transportation began requiring all airlines with at least 1 percent of all domestic traffic to report flightby-flight statistics on delays for the top 27 airports in the United States. ${ }^{11}$ This rule was passed as a result of a public outcry over the growth in air traffic delays in the 1980's. In

\footnotetext{
${ }^{11}$ A flight is defined as a nonstop segment.
}

addition, the major carriers covered by this rule agreed to voluntarily report data on all of their flights to or from the remaining domestic airports. Indeed, our data cover more than 250 airports. Originally, the data included the scheduled arrival and departure time of the flight, the actual arrival and departure time, whether the flight was canceled or diverted, and the flight number. From 1988-1994, airlines excluded information on flights that were delayed or canceled due to mechanical problems. Beginning in 1995, major carriers began reporting informa- 


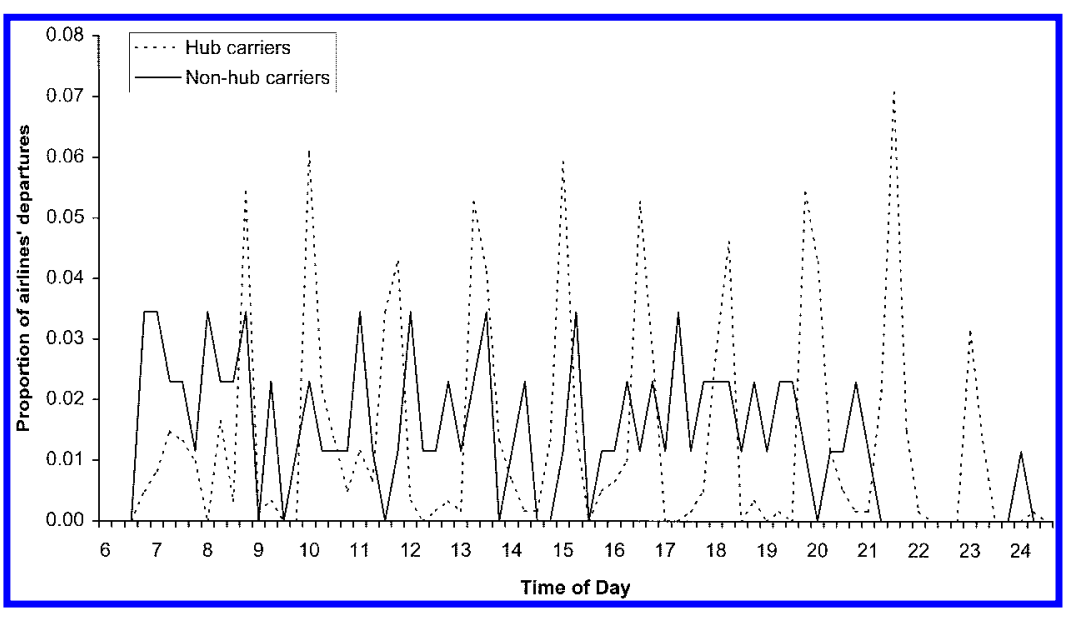

Figure 4. Departure Density for Hub and Non-Hub Carriers at Dallas-Fort Worth (DFW)

tion on all scheduled flights, regardless of the reason for a delay or cancellation. In that year, the data were expanded to include the time spent taxiing from the gate to the runway, actual flight time, time spent taxiing to the gate after landing, and the tail number of the aircraft. Our sample includes 66.4 million flights, which is all data over this time period with the exception of flights in five months that had substantially missing or corrupted data files. ${ }^{12}$

The most widely reported indicator of congestion is airline on-time performance: the percentage of flights that arrive within 15 minutes of scheduled arrival time. Canceled and diverted flights are treated as late arrivals. One problem with on-time performance as a measure of true delay is that airlines can manipulate it by adjusting their scheduled flight times to compensate for expected delays. However, the total cost to passengers and airlines from congestion or hubbing is a function of how much additional travel time these factors impose. Thus we construct a measure of delay that is unaffected by airline scheduling: actual travel time minus minimum feasible travel time. Minimum travel time is defined as the shortest observed travel time on a given nonstop route in a particular month. We consider the minimum feasible time to be a useful benchmark for what travel time would be if airports were sufficiently uncon-

\footnotetext{
12 The missing months are July and August 1993, March 1994, May 1999, and December 2000.
}

gested and weather were equally favorable. Netting out the minimum time controls for possible changes over time in the types of routes flown or in the performance of the air traffic control system that could affect average flying times. Routes are directional to allow for prevailing winds and other physical differences in travel, so we consider Philadelphia to Los Angeles to be a different route than Los Angeles to Philadelphia. Travel time is computed as the actual arrival time minus the scheduled departure time and thus includes delays in the flight leaving the gate.

Figure 5 plots average minimum travel time, scheduled travel time, and actual travel time. For consistency, the data used in Figure 5 include only routes where we observe flights in each month of the entire sample period. Actual travel time exceeds minimum travel time by more than 32 minutes in the year 2000. This number has increased more than 10 percent over the sample period, although as we mentioned earlier, changes in reporting between 1994 and 1995 could account for some of that growth. In addition, minimum travel time increased from 89 to 94 minutes over the time period, possibly due to greater traffic systemwide. ${ }^{13}$ Clearly

\footnotetext{
${ }^{13}$ Since the average route had over 150 flights even in 1988, our lowest-volume year, we believe we measure the minimum time with good accuracy. In principle, however, we are more likely to observe the true minimum travel time on routes with more flights and could overestimate the minimum time on sparse routes. We tried reestimating our
} 


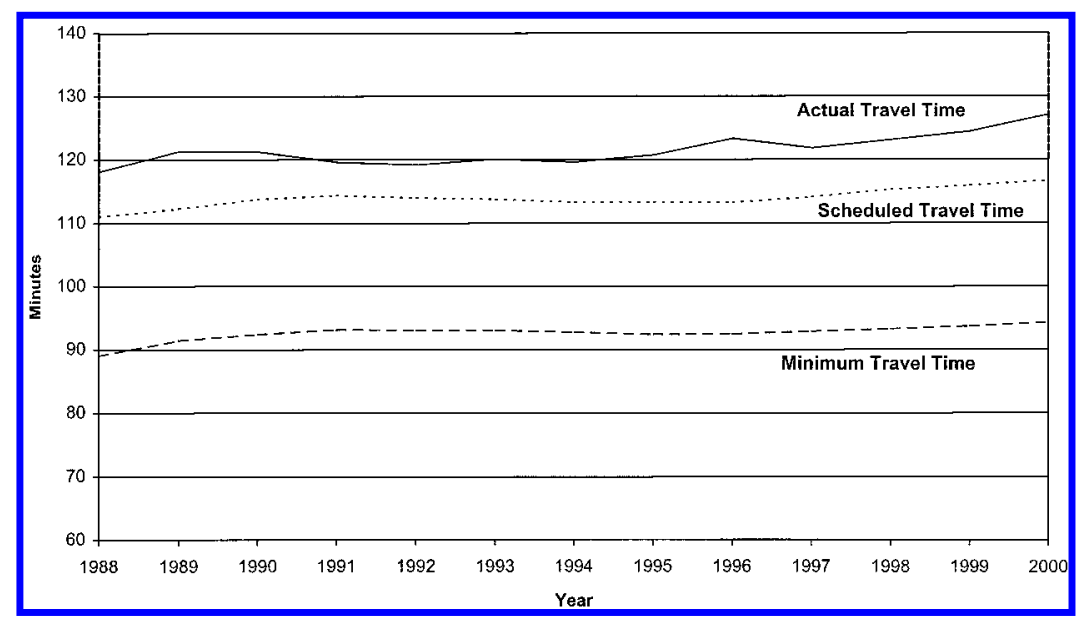

Figure 5. Minimum, Scheduled, and Actual Travel Times

carriers do not choose their schedules to have a mean delay of zero. The average delay from schedule of 9.9 minutes is both positive and large and has grown over time. In fact, airlines increased scheduled travel time by only about two-thirds of the growth in average travel time between 1988 and 2000.

We decompose the excess travel time into its component parts in Table 1. Over our sample period, the average flight required about 30 minutes more than the minimum feasible travel time on a route. Nearly 10 minutes of that excess is due to a late push-back from the gate. For flights after 1995, about one-half of the total excess travel time on the flight is spent midair, though much of that 16 minutes is probably due to less-than-favorable winds and weather en route. Overall, more than one in four flights is canceled or arrives at least 15 minutes late.

Following Section I, the measure of the size of the hub and thus the extent of network benefits should be the number of possible connections for a traveler through the hub. We define this variable as the number of other airports that an airline flies to from a given airport in a

major results with an alternative benchmark, the average travel time for the fastest decile of flights, so as to reduce our reliance on a single flight on a route. The coefficient estimates are slightly smaller this way, although the pattern of delays is the same. The small drop in magnitude of the coefficient estimates (approximately 10 percent) is likely due to the fact that even flights in the fastest decile of the distribution may be impacted by congestion at hubs. particular month. Airport concentration, which proxies for the extent to which delays are internalized by the carriers, is defined as the Herfindahl-Hirschman Index on the share of flights by the various airlines that serve that airport over each one-month period.

The bulk of flights in the United States are associated with hubs. Table 1 shows that nearly two-thirds of all flights in the sample originate at an airport that is a hub, with the hub carrier itself originating a little more than one-half of hub flights (39 percent of total flights). In all, 83 percent of flights either originate or land at some carrier's hub and almost three-quarters of all flights occur on an airline flying to or from its own hub. The typical airport has a HHI of 0.40 , although there is substantial variation across airports.

Table 2A identifies the hub carriers and reports airport concentration for all airports with at least 1 percent of the total flights in November 2000. Cincinnati, dominated by a Delta hub, was the most concentrated large airport that month at 0.91. Charlotte and Pittsburgh, both US Airways hubs, were close behind at 0.81 . Not every airport with a hub carrier is highly concentrated. Many single-hub airports are only moderately concentrated, such as Newark $(0.38$ with a large Continental hub) and Salt Lake City ( 0.48 with a large Delta hub). Hubs with less connection activity, such as United in San Francisco, have much lower concentrations (0.33). Some airports have multiple hub airlines, such as Chicago's O'Hare with United and American 
TABle 1 -Summary Statistics

\begin{tabular}{|c|c|c|}
\hline Variable & Mean & $\begin{array}{l}\text { Standard } \\
\text { deviation }\end{array}$ \\
\hline $\begin{array}{l}\text { Actual elapsed route time minus } \\
\text { minimum }+ \text { departure delay }\end{array}$ & 30.4 & 14.9 \\
\hline $\begin{array}{l}\text { Departure delay: actual push-back } \\
\text { time minus scheduled departure }\end{array}$ & 9.7 & 9.8 \\
\hline $\begin{array}{l}\text { Taxi-out time: time from push-back to } \\
\text { wheels-off-the-ground minus } \\
\text { minimum feasible time* }\end{array}$ & 9.8 & 5.0 \\
\hline $\begin{array}{l}\text { Actual flight time minus minimum } \\
\text { feasible flight time* }\end{array}$ & 16.1 & 9.4 \\
\hline $\begin{array}{l}\text { Taxi-in time: time from landing to } \\
\text { reaching the gate minus minimum } \\
\text { feasible time* }\end{array}$ & 4.1 & 2.3 \\
\hline Origin airport concentration & 0.40 & 0.21 \\
\hline \multicolumn{3}{|l|}{ Origin airport hub size: } \\
\hline 26-45 markets & 0.19 & 0.39 \\
\hline 46-70 markets & 0.24 & 0.43 \\
\hline $71+$ markets & 0.22 & 0.41 \\
\hline \multicolumn{3}{|l|}{ Origin airline hub size: } \\
\hline $26-45$ markets & 0.09 & 0.28 \\
\hline 46-70 markets & 0.15 & 0.35 \\
\hline $71+$ markets & 0.15 & 0.36 \\
\hline $\begin{array}{l}\text { Flight is traveling to or from a hub } \\
\text { airport }\end{array}$ & 0.83 & 0.38 \\
\hline $\begin{array}{l}\text { Flight is traveling to or from the } \\
\text { airline's own hub }\end{array}$ & 0.74 & 0.44 \\
\hline
\end{tabular}

Buffer: minutes between actual arrival and scheduled departure, spline terms:

\begin{tabular}{lcrc} 
& $\begin{array}{c}\text { Percent of } \\
\text { total }\end{array}$ & Mean & $\begin{array}{r}\text { Standard } \\
\text { deviation }\end{array}$ \\
\hline$<-120$ minutes* & 0.004 & -173 & 63 \\
0 to -120 minutes* & 0.061 & -29 & 27 \\
1 to 20 minutes* & 0.093 & 13 & 6 \\
21 to 40 minutes* & 0.191 & 31 & 6 \\
41 to 120 minutes* & 0.403 & 62 & 17 \\
$>120$ minutes* & 0.249 & 652 & 343 \\
\hline
\end{tabular}

Notes: Sample includes all flights for major carriers on Fridays from January 1988-November $2000(\mathrm{~N}=9,956,576)$, except for rows with $(*)$ which include Fridays from January 1995-November $2000(\mathrm{~N}=4,592,595)$. Also, data is missing for July and August 1993, March 1994, and May 1999. For rows 3-5, minimum feasible time is route and direction specific and is computed as the shortest amount of time required for a flight on a given route and month to taxi out, fly the route, and taxi in, respectively.

and only 0.38 concentration. Also, some busy airports do not have hubs with significant connecting activity: Chicago's Midway with a concentration of 0.71 or New York's LaGuardia which has a concentration of 0.22 .

Overall, there has been substantial consolidation since 1988, especially in the early 1990's, when mergers and bankruptcies reduced the number of major carriers in the sample from 14 to $10 .{ }^{14}$ The remaining airlines have continued to expand their hub and spoke systems, although a few carriers abandoned previous hubs. As a result, many airports looked quite different in 1988 than they do in the year 2000. Table 2B presents the same snapshot of all airports with at least 1 percent of the total flights in November 1988. For example, relative to 1988 , Denver and Atlanta each lost one of their hub carriers. Miami, Washington National, and Cleveland gained a single hub carrier, Las Vegas and Los Angeles gained two hub carriers, and Phoenix added a second hub carrier. JFK, Orlando, and Raleigh Durham lost their hubs altogether. Several cities had a change of hub airline or a change in the size of the hub. Finally, airport concentration has varied over this time period, with many airports exhibiting a general increase in concentration, a few airports exhibiting a strong rise in concentration as a single carrier consolidated its hubbing at that airport, and several airports showing a decline in concentration as hub carriers pulled out. In many regression specifications below, we will use this variation in hub size and concentration within an airport over time to identify their effects on excess travel time.

\section{Estimation and Results}

In this section, we examine the empirical predictions from Section I regarding the impact of network benefits and congestion externalities on delays. First, flights operating at hub airports should face delays that increase with the size of the hub. Second, most delays at hub airports should be incurred by the hub airline itself since the bulk of its flights are during congested peaks, and these delays should also be increasing in the size of the hub. Third, delays should be longer for flights that originate at a hub than flights arriving at a hub, as hub airlines cluster their departures more than their arrivals. Finally, congestion externalities should cause higher delays at less concentrated airports, holding the extent of hubbing constant.

To test these predictions, we estimate the following base empirical specification:

\footnotetext{
${ }^{14}$ See Morrison (1996) for a discussion of the policy issues relating to the merger trend in the airline industry.
} 
Table 2A-Hubbing and Concentration for Airports with at Least 1 Percent of FLIGHTS IN NOVEMBER 2000

\begin{tabular}{|c|c|c|c|c|}
\hline \multirow[b]{2}{*}{ Airport } & \multirow[b]{2}{*}{$\begin{array}{c}\text { Airport } \\
\text { concentration }\end{array}$} & \multicolumn{3}{|c|}{ Hub carriers with ... } \\
\hline & & $\begin{array}{c}71+ \\
\text { connections }\end{array}$ & $\begin{array}{c}46-70 \\
\text { connections }\end{array}$ & $\begin{array}{c}26-45 \\
\text { connections }\end{array}$ \\
\hline Atlanta & 0.72 & Delta & & \\
\hline Baltimore-Washington & 0.29 & & & Southwest \\
\hline Charlotte & 0.81 & & US Airways & \\
\hline Chicago O'Hare & 0.38 & United & American & \\
\hline Cincinnati & 0.91 & & Delta & \\
\hline Cleveland & 0.31 & & & Continental \\
\hline Dallas-Fort Worth & 0.52 & American & & Delta \\
\hline Denver & 0.57 & & United & \\
\hline Detroit & 0.63 & Northwest & & \\
\hline Houston Intercontinental & 0.61 & & Continental & \\
\hline Las Vegas & 0.25 & & & $\begin{array}{c}\text { America West, } \\
\text { Southwest }\end{array}$ \\
\hline Los Angeles & 0.19 & & & $\begin{array}{l}\text { American, } \\
\text { United }\end{array}$ \\
\hline Memphis & 0.66 & & & Northwest \\
\hline Miami & 0.37 & & & American \\
\hline Minneapolis-St. Paul & 0.66 & Northwest & & \\
\hline Nashville & 0.31 & & & Southwest \\
\hline Newark & 0.38 & & Continental & \\
\hline Philadelphia & 0.50 & & US Airways & \\
\hline Phoenix & 0.30 & & America West & Southwest \\
\hline Pittsburgh & 0.81 & & US Airways & \\
\hline Saint Louis & 0.52 & & Trans World & \\
\hline Salt Lake City & 0.48 & & & Delta \\
\hline San Francisco & 0.33 & & & United \\
\hline Washington Dulles & 0.39 & & & United \\
\hline Washington National & 0.23 & & & US Airways \\
\hline
\end{tabular}

Notes: Airports with at least 1 percent of flights in November 2000 but without a large hub carrier are (concentration in parentheses): Boston (0.29), Chicago Midway (0.71), Houston Hobby (0.84), LaGuardia (0.22), Kansas City (0.23), Oakland (0.47), Orlando (0.19), Portland (0.19), San Diego (0.21), San Jose (0.24), Seattle (0.23), Tampa (0.18).

$$
\begin{aligned}
& \text { DELAY }_{i j k m t} \\
& =\alpha+\beta_{1} \text { CONCENTRATION }_{\text {org }, k t} \\
& +\beta_{2} \text { CONCENTRATION }_{d e s t, m t} \\
& +\theta_{1}\left(\mathrm{HUB} \text { AIRPORT }{ }_{\text {org }}\right)_{k t} \\
& +\theta_{2}\left(\text { HUB AIRPORT }_{d e s t}\right)_{m t} \\
& +\gamma_{1}\left(\text { HUB AIRLINE } \times \text { HUB AIRPORT }{ }_{o r g}\right)_{j k t} \\
& +\gamma_{2}\left(\text { HUB AIRLINE } \times \text { HUB AIRPORT }{ }_{d e s t}\right)_{j m t} \\
& +\Psi_{1}\left(\text { DEMAND }_{o r g}\right)_{m t}+\Psi_{2}\left(\text { DEMAND }_{d e s t}\right)_{m t} \\
& +\delta_{1} \mathrm{YEAR}_{t}+\delta_{2} \mathrm{MONTH}_{t}+\delta_{3} \operatorname{AIRLINE}_{j} \\
& +\delta_{4} \mathrm{AIRPORT}_{\text {org }, k}+\delta_{5} \mathrm{AIRPORT}_{\text {dest }, m}+\varepsilon_{i j k m t}
\end{aligned}
$$

where DELAY is the measure of excess travel time for flight $i$ on airline $j$ from airport $k$ to airport $m$ on date $t$. CONCENTRATION refers to the airport concentration of the origin $(k)$ or destination $(m)$ airport. HUB is measured both at the airport level (whether airport $k$ is a hub for any airline) and the airline level (whether airline $j$ has a hub at airport $k$ ). An airline's hub is defined as a function of the number of airports airline $j$ flies to/from airport $k$. We generate dummy variables for three different ranges of the number of destination airports: 26 to 45,46 to 70 , and 71 or more. ${ }^{15}$ Concentration and hub

\footnotetext{
${ }^{15}$ Our results are robust to alternative functional form assumptions, but we find that the categories provide a better fit than a linear function and are more easily interpretable than a higher-order polynomial.
} 
Table 2B-Hubbing and Concentration for Airports with at Least 1 Percent of FLIGHTS IN NOVEMBER 1988

\begin{tabular}{|c|c|c|c|c|}
\hline \multirow[b]{2}{*}{ Airport } & \multirow[b]{2}{*}{$\begin{array}{c}\text { Airport } \\
\text { concentration }\end{array}$} & \multicolumn{3}{|c|}{ Hub carriers with ... } \\
\hline & & $\begin{array}{c}71+ \\
\text { connections }\end{array}$ & $\begin{array}{c}46-70 \\
\text { connections }\end{array}$ & $\begin{array}{c}26-45 \\
\text { connections }\end{array}$ \\
\hline Atlanta & 0.43 & Delta & Eastern & \\
\hline Baltimore-Washington & 0.47 & & & Piedmont \\
\hline Charlotte & 0.80 & & Piedmont & \\
\hline Chicago O'Hare & 0.35 & United & American & \\
\hline Cincinnati & 0.54 & & Delta & \\
\hline Dallas-Fort Worth & 0.44 & American & Delta & \\
\hline Denver & 0.38 & & $\begin{array}{l}\text { Continental, } \\
\text { United }\end{array}$ & \\
\hline Detroit & 0.45 & & Northwest & \\
\hline Houston Intercontinental & 0.51 & & Continental & \\
\hline Memphis & 0.63 & & Northwest & \\
\hline Minneapolis-St. Paul & 0.60 & & Northwest & \\
\hline Nashville & 0.40 & & & American \\
\hline Newark & 0.27 & & & Continental \\
\hline New York JFK & 0.18 & & & TWA \\
\hline Orlando & 0.17 & & & Delta \\
\hline Philadelphia & 0.23 & & & USAir \\
\hline Phoenix & 0.28 & & & America West \\
\hline Pittsburgh & 0.69 & USAir & & \\
\hline Raleigh-Durham & 0.41 & & & American \\
\hline Saint Louis & 0.61 & Trans World & & \\
\hline Salt Lake City & 0.62 & & Delta & \\
\hline San Francisco & 0.20 & & & United \\
\hline Washington Dulles & 0.47 & & & United \\
\hline
\end{tabular}

Notes: Airports with at least 1 percent of flights in November 1988 but without a large hub carrier are (concentration in parentheses): Boston (0.12), Cleveland (0.21), Houston (0.41), LaGuardia (0.12), Las Vegas (0.24), Los Angeles (0.13), Miami (0.19), San Diego (0.13), Seattle (0.16), Tampa (0.14), and Washington National (0.12).

are included separately for both the origin and destination airports to allow for separate effects for each end of the flight.

We also include DEMAND variables to control for changes in local demand for air travel over time and across Metropolitan Statistical Areas (MSAs) that might lead to greater flight delays, including annual population, employment, and per capita income. For airports in a MSA, we include their MSA values, but also interact the economic variables with a dummy variable that equals one if the airport is the largest airport in the MSA, a proxy for the likeliest airport to be a hub. For airports not in a MSA, we interact a non-MSA dummy or Alaska airport dummy with national values of the economic variables. ${ }^{16}$ Most of these eco-

\footnotetext{
${ }^{16}$ Almost all airports in our data set that are not in an MSA and not in Alaska are located at destination vacation spots. Many are airports at ski resort locations.
}

nomic variables are of the expected sign and are statistically significant.

All specifications have dummies for the year and month of travel to control for unobserved time and seasonal factors that may affect systemwide delays, and for the airline, $j$, to control for airline-specific scheduling factors. Finally, most specifications are run with a full set of fixed effects for the airport the flight originates from $(k)$ and the airport it arrives at $(m)$ to control for unobserved airport heterogeneity that may affect delays, such as capacity.

Given that we have data on more than 66 million flights, we take two steps to make estimation more manageable. First, we narrow our data to all flights on Fridays. ${ }^{17}$ Second, in our

\footnotetext{
${ }^{17}$ We construct the independent variables in our regressions using all data, not just Fridays. In addition, we have conducted some preliminary estimation on Saturdays, the least busy day of the week, and obtain the same basic results.
} 
Table 3A-The Effect of Airline Hubbing and Airport Concentration ON TRAVEL Time

\begin{tabular}{|c|c|c|c|c|c|c|}
\hline \multicolumn{7}{|c|}{ Dependent variable: Travel time in excess of minimum feasible } \\
\hline & \multicolumn{2}{|c|}{$\begin{array}{c}\text { Whole sample } \\
\text { (1) } \\
\text { Ordinary } \\
\text { least squares }\end{array}$} & \multicolumn{2}{|c|}{$\begin{array}{c}\text { Whole sample } \\
\text { (2) } \\
\text { Instrumental } \\
\text { variable }\end{array}$} & \multicolumn{2}{|c|}{$\begin{array}{c}\text { Whole sample } \\
\text { (3) } \\
\text { Ordinary } \\
\text { least squares }\end{array}$} \\
\hline & Origin & Destination & Origin & Destination & Origin & Destination \\
\hline \multicolumn{7}{|l|}{ Airport hub size } \\
\hline 26-45 markets & $\begin{array}{c}4.07 \\
(0.26)\end{array}$ & $\begin{array}{c}2.34 \\
(0.28)\end{array}$ & $\begin{array}{c}4.52 \\
(0.19)\end{array}$ & $\begin{array}{c}-0.31 \\
(0.17)\end{array}$ & $\begin{array}{c}-0.53 \\
(0.23)\end{array}$ & $\begin{array}{c}-1.01 \\
(0.20)\end{array}$ \\
\hline 46-70 markets & $\begin{array}{c}6.67 \\
(0.33)\end{array}$ & $\begin{array}{l}3.62 \\
(0.34)\end{array}$ & $\begin{array}{c}6.20 \\
(0.22)\end{array}$ & $\begin{array}{c}-0.85 \\
(0.21)\end{array}$ & $\begin{array}{c}1.93 \\
(0.32)\end{array}$ & $\begin{array}{c}0.82 \\
(0.31)\end{array}$ \\
\hline $71+$ markets & $\begin{array}{l}7.25 \\
(0.42)\end{array}$ & $\begin{array}{c}4.49 \\
(0.42)\end{array}$ & $\begin{array}{c}5.44 \\
(0.15)\end{array}$ & $\begin{array}{c}0.79 \\
(0.14)\end{array}$ & $\begin{array}{c}4.12 \\
(0.36)\end{array}$ & $\begin{array}{c}1.92 \\
(0.35)\end{array}$ \\
\hline Airport concentration & $\begin{array}{c}-6.38 \\
(0.57)\end{array}$ & $\begin{array}{c}-6.97 \\
(0.60)\end{array}$ & $\begin{array}{c}-4.82 \\
(0.24)\end{array}$ & $\begin{array}{c}-1.38 \\
(0.24)\end{array}$ & $\begin{array}{c}-1.29 \\
(0.55)\end{array}$ & $\begin{array}{c}-2.93 \\
(0.54)\end{array}$ \\
\hline Airport fixed effects & \multirow{2}{*}{\multicolumn{2}{|c|}{ No }} & \multicolumn{2}{|r|}{ No } & \multicolumn{2}{|r|}{ Yes } \\
\hline$R^{2}$ & & & \multirow{2}{*}{\multicolumn{2}{|c|}{617,150}} & \multicolumn{2}{|c|}{0.34} \\
\hline $\begin{array}{l}\text { Number of } \\
\text { observations }\end{array}$ & \multicolumn{2}{|c|}{617,150} & & & \multicolumn{2}{|c|}{617,150} \\
\hline
\end{tabular}

Notes: Robust standard errors are in parentheses. Regressions are based on the mean of the dependent and independent variables for each airline on every route for all months in every year. Equations also include indicator variables for year, month, and airline, and various economic demand variables that are described in the paper.

base specification we generate cells of flights by each airline on every route for all months in every year, a total of 617,150 airline-routemonth-year cells. Within each cell we compute the mean of the dependent variable and all independent variables and use these cell means in the regressions that are reported in this paper. These regressions are weighted by the number of flights within the cell. These weighted leastsquares coefficient estimates are identical to what we would find using ordinary least squares (OLS), since none of the independent variables in our basic specification vary within the cells. We compute robust standard errors, allowing the residuals to be correlated over time within a route.

\section{A. Airport-Level Findings}

Below, we find large and significant effects of hubbing and moderate effects of concentration on delays. Our initial evidence is presented in Table 3A. The dependent variable is excess travel time above the minimum feasible travel time. Consistent with our characterization of network benefits from hubbing, hub airports have more delays. In column (1), flights origi- nating and arriving at hub airports face delays of up to 7.2 and 4.5 minutes, respectively. In addition, hub delays increase monotonically in the size of the hub. Flights that originate from the smallest hubs are delayed four minutes more than flights departing from non-hub airports, 6.7 minutes at medium-size hubs, and 7.2 at the largest ones. A similar pattern holds for flights flying to hub airports, although the coefficients are uniformly smaller in magnitude.

We also find evidence that airports with low concentration have higher delays, possibly because carriers do not fully internalize the costs their flights impose on other carriers. In column (1), higher concentration has a small but beneficial impact on delays. Controlling for the extent of hubbing, a one-standard-deviation increase in concentration (0.20) leads to a modest 1.3-minute decline in delay at origin airports. Even an increase from the mean concentration level of 0.40 at an origin airport to an airport with just one airline leads to just a 3.8-minute decrease in delays, smaller than the effect of hubbing.

One potential problem with this regression is the possibility that the income, employment, and population variables might not fully control 
for local demand. In particular, airports with high unobserved local demand for air travel might have a greater number of flights and also have a hub that serves a large number of destinations. Thus high levels of congestion may be due to local demand rather than hubbing. To address this issue, we take two approaches.

In column (2), we instrument for the probability that an airport is a hub with variables that are based on the demand for connections by surrounding communities, rather than by the hub city. We compute the distance from a given airport to all of the other airports in our sample, counting the number of airports within 500 miles, 500-1000 miles, and 1000-1500 miles, and also sum up the population and per capita income for the airports within each of those rings. This gives the total demand for connections around each airport, both in terms of number of connecting airports and economic buying power of the potential connections. The demand variables are also interacted with a dummy variable that indicates the primary airport within each MSA. Such an interaction is important to differentiate the largest airport from smaller secondary airports within an MSA. These instruments are significant in the first stage and are moderately successful in isolating the hub delay effect from local demand. For origin airports, the hub variables are still individually and jointly significant and nearly as large as the OLS coefficients, suggesting that hubs are associated with greater congestion. However, the destination hub variables are much smaller than the OLS coefficients and are not statistically significant. While the instruments can successfully identify hubs, separate origin and destination effects may be harder to pin down. Overall, the estimation is consistent with greater origination delays at hub airports.

In the third column we include airport fixed effects. By effectively looking only at changes over time within airports in hubbing, concentration, and delays, we absorb time-invariant airport-level factors such as capacity or local demand. However, by including fixed effects, we eliminate a large source of variationdifferences in hubbing and delays across airports. The fixed-effects estimates present the same pattern as the earlier estimation, except the coefficients are considerably smaller. The biggest hubs have the largest delays and delays increase with the size of the hub. The coefficient on the smallest category of origin and destination hubs is negative, suggesting that these hubs appear to have slightly better performance than non-hub airports. However, the negative coefficients themselves are small. Concentration also reduces delays, although the coefficients are much smaller than in the estimates that do not include fixed effects. To the extent that cross-sectional variation is required to identify airport-level hubbing and concentration effects, the fixed-effects estimates might provide a lower bound on the true effects.

\section{B. Within-Airport Clustering of Flights}

In Table 3B, column (1), we move on to consider an important implication of our model of network benefits: that the hub carrier should have greater delays than non-hub carriers at hub airports. In this case we include separate covariates for flights by the hub carrier to or from its own hub airport. With airport fixed effects, the hub/non-hub carrier effect is identified based on differences between hub and non-hub airlines within each airport, so all carriers at the airport are subject to identical capacity constraints and face the same level of local demand. The results suggest that the dominant hub carrier incurs most delays at hub airports. Relative to non-hub airlines at the same airport, hub airlines have excess travel time of up to 5.6 minutes at origin airports and 2.8 minutes at destination airports. Estimated delays accruing to the hub airline increase monotonically in the size of the hub and are larger for origin airports. All of these results are consistent with the existence of strong network benefits that lead to more delays for hub airlines. This result also supports the view that the peaks of traffic occur at hubbing times rather than merely popular times to fly. If the latter were the case, then non-hub carriers would have just as strong a desire to fly during the most congested peaks and their flights would be delayed just as much as the hub carriers. To the degree that delays between the two types of airlines differ, it is evidence for hub aircraft having greater value of flying in the peaks due to the network benefits. ${ }^{18}$

\footnotetext{
${ }^{18}$ While hub and non-hub flight densities are virtually uncorrelated, the share of hub flights scheduled at congested peaks is quite high and non-hub flights are scheduled
} 
Table 3B-The Effect of Airline Hubbing and Airport Concentration ON TRAVEL TIME

\begin{tabular}{|c|c|c|c|c|}
\hline \multicolumn{5}{|c|}{ Dependent variable: Travel time in excess of minimum feasible } \\
\hline & \multicolumn{2}{|c|}{$\begin{array}{c}\text { Whole sample } \\
\text { (1) } \\
\text { Ordinary least squares }\end{array}$} & \multicolumn{2}{|c|}{$\begin{array}{c}\text { Whole sample excluding } \\
\text { slot-constrained airports } \\
(2) \\
\text { Ordinary least squares }\end{array}$} \\
\hline & Origin & Destination & Origin & Destination \\
\hline \multicolumn{5}{|l|}{ Airline hub size } \\
\hline 26-45 markets & $\begin{array}{c}3.38 \\
(0.34)\end{array}$ & $\begin{array}{c}0.28 \\
(0.35)\end{array}$ & $\begin{array}{c}3.04 \\
(0.34)\end{array}$ & $\begin{array}{c}-0.0012 \\
(0.35)\end{array}$ \\
\hline 46-70 markets & $\begin{array}{c}5.24 \\
(0.39)\end{array}$ & $\begin{array}{c}1.97 \\
(0.41)\end{array}$ & $\begin{array}{c}4.61 \\
(0.38)\end{array}$ & $\begin{array}{c}1.38 \\
(0.39)\end{array}$ \\
\hline $71+$ markets & $\begin{array}{c}5.62 \\
(0.45)\end{array}$ & $\begin{array}{c}2.82 \\
(0.46)\end{array}$ & $\begin{array}{c}5.62 \\
(0.48)\end{array}$ & $\begin{array}{c}2.52 \\
(0.45)\end{array}$ \\
\hline \multicolumn{5}{|l|}{ Airport hub size } \\
\hline 26-45 markets & $\begin{array}{c}-1.85 \\
(0.27)\end{array}$ & $\begin{array}{c}-0.87 \\
(0.26)\end{array}$ & $\begin{array}{c}-0.74 \\
(0.26)\end{array}$ & $\begin{array}{c}-0.11 \\
(0.27)\end{array}$ \\
\hline 46-70 markets & $\begin{array}{c}-0.79 \\
(0.39)\end{array}$ & $\begin{array}{c}0.07 \\
(0.40)\end{array}$ & $\begin{array}{c}0.74 \\
(0.39)\end{array}$ & $\begin{array}{l}1.25 \\
(0.40)\end{array}$ \\
\hline $71+$ markets & $\begin{array}{l}1.04 \\
(0.47)\end{array}$ & $\begin{array}{c}0.50 \\
(0.47)\end{array}$ & $\begin{array}{c}2.22 \\
(0.49)\end{array}$ & $\begin{array}{c}1.44 \\
(0.48)\end{array}$ \\
\hline Airport concentration & $\begin{array}{c}-1.73 \\
(0.54)\end{array}$ & $\begin{array}{c}-2.65 \\
(0.54)\end{array}$ & $\begin{array}{c}-3.24 \\
(0.55)\end{array}$ & $\begin{array}{c}-3.85 \\
(0.54)\end{array}$ \\
\hline Airport fixed effects & & & & \\
\hline & & & & \\
\hline Number of observations & & 150 & & 962 \\
\hline
\end{tabular}

Notes: Robust standard errors are in parentheses. Regressions are based on the mean of the dependent and independent variables for each airline on every route for all months in every year. Equations also include indicator variables for year, month, and airline, and various economic demand variables that are described in the paper.

In this regression, airport-level hub variables indicate the extent of delays by non-hub airlines at a hub airport. In column (1), the coefficients on the airport-level variables become much smaller in magnitude, and are sometimes even negative. The negative coefficient indicates that the non-hub airlines have slightly lower delays when they operate at smaller hubs rather than at non-hub airports, possibly benefitting from scheduling some of their flights at times when there are few hub airline flights. Even with these changes, the results suggest that the performance of non-hub carriers deteriorates monotonically with hub size and that non-hub carriers at the largest hubs face worse delays than carriers that operate at airports without a hub. Airport concentration remains negative and sta-

$\overline{\text { diffusely throughout the day. Hence the result that delays }}$ accrue mainly to hub carriers. tistically significant, but its estimated magnitude in the fixed-effects specifications is small when compared to the hub variables. A large increase in the HHI from 0.40 to 1.0 leads to a 1.1- to 1.6-minute decrease in delays, less than one-third of the increase in travel time associated with the largest hub airlines.

While hub carriers need to cluster their departures to maximize network connection benefits, Section I shows that they can smooth their arrivals somewhat as long as the cost of long connections is not too high. If delays come from peak loads of traffic at hubs, arrivals should exhibit lower hub-induced delays than the more clustered departures. Our results support this conclusion since the effect of hubbing on originating flights is much larger than on arriving flights in every specification. The delays due to concentration do not depend on clustering of flights and thus should not exhibit a systematic pattern of being larger for origin or destination 
airports. Indeed, the estimated concentration effects are similar for both types of airports.

Finally, we consider one other factor potentially affecting our results. During the sample period, airlines were free to choose their preferred number of flights at all but four airports-Chicago O'Hare, New York JFK, New York LaGuardia, and Washington Nationalwhere the FAA set a cap on hourly departures. Since these airports have low HHIs, our estimated coefficients on concentration might be biased downwards because these airports might have been more congested were it not for the departure caps. We examine this possibility in column (2) of Table 3B by excluding all flights originating or departing from one of the four slot-constrained airports. As expected, the coefficients on concentration increase appreciably from those in column (1), but the overall conclusions remain the same. For example, an increase in the HHI from 0.40 to 1.0 leads to a 1.9- to 2.3-minute decrease in excess travel time, still much smaller than the difference in excess travel time between a non-hub and a large hub carrier.

\section{Further Exploration}

The results in Tables 3A and 3B suggest that hub carriers are willing to accept substantial delays on their own flights, even at airports where they control a large proportion of the total flights. We investigate the reasons behind these delays and the robustness of these results using more detailed data beginning in 1995 that allow us to track the movement of individual aircraft and to decompose overall travel time into time spent taxiing out to the runway, in the air, and taxiing in to the gate at the destination.

To begin, we consider the possibility that increased hub airline delays at the origin airport relative to the destination are due to late arriving aircraft from previous flights, so called "cascading" delays. If an aircraft is delayed arriving at a hub, then it may be more likely to be delayed on departure, potentially leading us to doublecount delays. In this case, controlling for late arrivals in our regressions would reduce the estimated effect of hubbing on departure delays. However, this logic assumes that scheduled connection time is the same for hub and nonhub airlines. Since a hub airline faces additional costs from late arrivals due to potential missed
Table 4-Median Number of Minutes of Scheduled Buffer Between Aircraft Arrival and Departure: 1995-2000

\begin{tabular}{lcc}
\hline \hline Airport hub size & Non-hub carrier & Hub carrier \\
\hline None & 40 & \\
$26-45$ markets & 46 & 47 \\
$46-70$ markets & 50 & 53 \\
$71+$ markets & 45 & 56 \\
\hline
\end{tabular}

Notes: Includes all flights with a scheduled buffer of three hours or less in order to exclude aircraft that remain at an airport overnight. Based on a 2-in-5 sample of all flights on Fridays.

connections, it has incentives to schedule longer layovers than the non-hub carrier. With a longer scheduled layover, or buffer, at their hub, a hub airline could still turn around a delayed aircraft and have it depart on schedule, mitigating cascading delays from late-arriving flights.

As it turns out, hub carriers do schedule longer times on the ground for their aircraft at their hubs. For flights after 1995, we use data on the aircraft tail numbers to compute a variable called "scheduled buffer," defined as the difference between the scheduled arrival time of the airplane from its previous flight and its next scheduled departure time. Table 4 reports the median number of minutes of scheduled buffer, broken out by whether the flight was on a hub carrier and the size of the hub. ${ }^{19}$ The median scheduled time on the ground is 40 minutes at airports where there is no hubbing. Non-hub carriers at hub airports schedule somewhat longer buffer times, ranging from 45 to $50 \mathrm{~min}-$ utes. Hub carriers, however, schedule yet longer buffers, ranging from 47 to 56 minutes. The scheduled buffer for hub carriers, and the difference between hub and non-hub carriers for a given airport hub size, increases with hub size.

To see how this extra padding on the ground affects our delay results, we repeat our estimation controlling for the actual buffer, which is the scheduled departure time minus the actual arrival time. This definition of buffer measures the actual time the plane has to be "turned around" once at the gate, thus taking into

\footnotetext{
${ }^{19}$ We use median scheduled time on the ground rather than the mean in order to reduce the skewness caused by planes parking at the airport overnight. To this end, in Table 4 we also exclude all observations with a buffer of three hours or more.
} 
Table 5-The Effect of Late-Arriving Aircraft on

Excess Travel Time Due to Airline Hubbing and Airport CONCENTRATION: 1995-2000

Dependent variable: Travel time in excess of minimum feasible

\begin{tabular}{|c|c|c|c|c|}
\hline & \multicolumn{2}{|r|}{$(1)$} & \multicolumn{2}{|r|}{$(2)$} \\
\hline & Origin & Destination & Origin & Destination \\
\hline \multicolumn{5}{|l|}{ Airline hub size } \\
\hline 26-45 markets & $\begin{array}{c}3.33 \\
(0.10)\end{array}$ & $\begin{array}{r}-0.28 \\
(0.10)\end{array}$ & $\begin{array}{l}2.45 \\
(0.13)\end{array}$ & $\begin{array}{r}-0.48 \\
(0.13)\end{array}$ \\
\hline 46-70 markets & $\begin{array}{c}8.02 \\
(0.12)\end{array}$ & $\begin{array}{c}3.19 \\
(0.12)\end{array}$ & $\begin{array}{c}5.00 \\
(0.15)\end{array}$ & $\begin{array}{c}1.52 \\
(0.15)\end{array}$ \\
\hline $71+$ markets & $\begin{array}{l}9.38 \\
(0.12)\end{array}$ & $\begin{array}{l}4.93 \\
(0.12)\end{array}$ & $\begin{array}{l}5.08 \\
(0.15)\end{array}$ & $\begin{array}{l}2.21 \\
(0.15)\end{array}$ \\
\hline \multicolumn{5}{|l|}{ Airport hub size } \\
\hline 26-45 markets & $\begin{array}{c}-2.69 \\
(0.13)\end{array}$ & $\begin{array}{c}-1.51 \\
(0.13)\end{array}$ & $\begin{array}{r}-3.49 \\
(0.17)\end{array}$ & $\begin{array}{r}-1.86 \\
(0.17)\end{array}$ \\
\hline 46-70 markets & $\begin{array}{c}-3.49 \\
(0.22)\end{array}$ & $\begin{array}{c}-1.18 \\
(0.23)\end{array}$ & $\begin{array}{c}-2.93 \\
(0.29)\end{array}$ & $\begin{array}{c}-1.25 \\
(0.29)\end{array}$ \\
\hline $71+$ markets & $\begin{array}{c}-3.21 \\
(0.26)\end{array}$ & $\begin{array}{c}-2.02 \\
(0.23)\end{array}$ & $\begin{array}{c}-1.98 \\
(0.34)\end{array}$ & $\begin{array}{c}-0.94 \\
(0.34)\end{array}$ \\
\hline $\begin{array}{l}\text { Airport } \\
\quad \text { concentration }\end{array}$ & $\begin{array}{r}-1.40 \\
(0.67)\end{array}$ & $\begin{array}{c}-2.03 \\
(0.67)\end{array}$ & $\begin{array}{c}-2.54 \\
(0.85)\end{array}$ & $\begin{array}{c}-1.38 \\
(0.85)\end{array}$ \\
\hline \multicolumn{5}{|l|}{ Buffer size } \\
\hline $\begin{array}{r}<-120 \\
\text { minutes }\end{array}$ & \multicolumn{2}{|c|}{$\begin{array}{c}-0.767 \\
(0.007)\end{array}$} & & \\
\hline $\begin{array}{r}0 \text { to }-120 \\
\text { minutes }\end{array}$ & \multicolumn{2}{|c|}{$\begin{array}{r}-1.036 \\
(0.003)\end{array}$} & & \\
\hline 1 to 20 minutes & \multicolumn{2}{|c|}{$\begin{array}{c}-1.064 \\
(0.011)\end{array}$} & & \\
\hline $\begin{array}{l}21 \text { to } 40 \\
\text { minutes }\end{array}$ & \multicolumn{2}{|c|}{$\begin{array}{c}-0.567 \\
(0.008)\end{array}$} & & \\
\hline $\begin{array}{l}41 \text { to } 120 \\
\text { minutes }\end{array}$ & \multicolumn{2}{|c|}{-0.012} & & \\
\hline $\begin{array}{l}>120 \\
\text { minutes }\end{array}$ & \multicolumn{2}{|c|}{$\begin{array}{l}0.030 \\
(0.0001)\end{array}$} & & \\
\hline$R^{2}$ & \multicolumn{2}{|r|}{0.42} & \multicolumn{2}{|r|}{0.07} \\
\hline
\end{tabular}

Notes: Robust standard errors are in parentheses. Regressions also include indicator variables for year, month, airport, and airline, and various economic demand variables that are described in the paper. Based on a 2-in-5 sample of all flights on Fridays $(\mathrm{N}=1,767,565)$.

account both the scheduled buffer from the previous table and also the likelihood that the flight will arrive late. Given that hub flights have longer scheduled buffers, but are more likely to arrive late, the expected impact of controlling for the actual buffer on hub delays is unclear.

In Table 5 we present the same base regression with fixed effects from column (1) of Table $3 \mathrm{~B}$ with the addition of spline terms for various levels of buffers: greater than 120 minutes, 41 to 120 minutes, 21 to 40 minutes, 1 to 20 minutes, 0 to -120 minutes, and less than -120 minutes. $^{20}$ The last two categories reflect aircraft that arrive after their next scheduled departure. The first column includes the base regression with the spline terms, and the second column is the base regression run only on the 1995 to 2000 sample period for comparison. Since the buffer variable is flight-specific, we use flight-level data rather than the cell aggregates in Tables $3 \mathrm{~A}$ and $3 \mathrm{~B}$. Due to computer memory limitations, we use a random sample of 40 percent of the flights on Fridays.

The results in Table 5 suggest that while a late arrival is a good predictor of whether an aircraft departs late, it does not explain the excess delays created by hubbing. In fact, comparing columns (1) and (2), when we control for the buffer the hub airline coefficients nearly double in size and significance. This result implies that the congestion faced by hub airlines at hub airports relative to non-hub airlines is greater than was reported in Tables 3A and 3B. However, only some of that congestion manifests itself in passenger delays since the hub airline partially offsets it by scheduling longer layovers than non-hub airlines. ${ }^{21}$

The coefficients on the buffer spline terms are all of the expected sign and significance. The coefficient on each spline term is interpreted as the marginal impact of an aircraft arriving a little later within a given buffer time period on the departure time of the aircraft on its next flight. The results show that buffer has little additional impact on flights already arriving more than 40 minutes before their next departure. Airlines can make up about one-half of additional delay $(1-0.567)$ when aircraft arrive between 21 and 40 minutes prior to the next scheduled departure by turning the aircraft around quickly, but travel time increases about

\footnotetext{
${ }^{20}$ We allow the kinks in the spline function to be discontinuous by adding indicator variables for each interval. To conserve space, we only report the estimated slopes on the spline function. There is very little difference, either qualitatively or statistically, if we force the function to be continuous.

${ }^{21}$ When we decompose excess travel time into its various components, a procedure which is described below, we find that controlling for buffer only increases the measured hub effect on delays in pushing back from the gate. The effect of hubbing on the other portions of the flight (taxi-out time, flight time, and taxi-in time) is unchanged to within one second. We take this as strong evidence that our interpretation of the buffer mechanism is correct.
} 
one-for-one (1.064) for flights whose inbound aircraft had a buffer of less than 20 minutes. The fact that delays do not increase one-for-one for the latest arriving category, more than 120 minutes late, may be due to airlines deciding to either cancel or substitute another aircraft for some very late flights.

The airport concentration effects are much lower in both specifications that use the 1995 to 2000 sample period. With fixed effects, the coefficient on concentration is identified only by changes in concentration within airports over a six-year period. While there were many significant changes in concentration and hubbing within airports between 1988 and 2000, most of those changes had already taken place by 1995 , leaving little variation with which to identify the concentration coefficient.

To further examine the robustness of our findings regarding hubs, we decompose excess travel time into its various components, including delay in departure from the gate, time spent taxiing to the runway, travel time midair, and taxi time to the gate at the destination airport. As with total travel time, each component is measured as the excess from the minimum observed on the route during the month. (The minimum departure delay is imposed to be zero.) To the extent that the delays on hub carriers are due to hubbing, we should be able to isolate these effects at the origin and destination airports. $^{22}$

\footnotetext{
${ }^{22}$ Several seminar participants and a referee have suggested that variation in speed among aircraft types may explain some of the differences in travel time relative to minimum travel time on various routes. We provide two responses. In Table 6, we show that most hubbing-related delays occur on the ground at either the origin or destination airport, casting doubt on the likelihood that differences in aircraft types flown by hub and non-hub carriers can explain these results. In addition, we have estimated the specifications in Tables 3 and 6 controlling for route distance, aircraft type, and distance interacted with aircraft type. These added covariates reduce the estimated magnitudes somewhat, but the qualitative and statistical conclusions remain the same. In particular, the estimated excess taxi-in times, taxi-out times, and departure delays at the largest hubs decline only about 10 percent but the excess flying time falls from 1.3 minutes to 0.13 minutes when traveling to the hub airline's largest hub, and from 1.3 minutes to 0.70 minutes when traveling to a 46-70 destination hub. Since the distances hub carriers fly and the aircraft types they use at their hubs are choice variables, we suspect that at least some of the differences are due to these variables capturing some delay that is actually caused by hubbing.
}

Table 6 contains regression results using these four dependent variables in our base specification, with all data aggregated into cells. Given that the short time period with the airport dummies makes it difficult to identify airportlevel effects, we will focus on the within-airport hub airline coefficients. The results are consistent with the network benefits view of delays. For hub carrier flights originating at their hub, most delays involve a late departure from the gate or increased time on the taxiway, with the same increasing delays with hub size that we saw in Tables 3A and 3B. In fact, the sum of hub airline coefficients in column (1) for departure delay and column (2) for taxi-out time is nearly exactly equal to our total estimated delay for flights originating at a hub in Table 5, column (2). Originating at a large hub accounts for 30 percent of the average departure delay and 17 percent of the average excess delay waiting to take off. Originating at a hub has virtually no effect on excess flying time or time spent on the taxiway at the destination.

Airline flights to their own hub require about a minute more time midair, possibly due to air traffic queues into the hub airport. Arriving hub flights also have two minutes longer excess taxi times to their gates, accounting for one-half of the average, with the delays increasing with the size of the hub. Once again, flying to a hub does not affect delays at the origination airport as the departure delays and taxi-out time effects are almost always indistinguishable from zero.

These regressions help highlight the sources of hub delays. Inbound hub aircraft spending additional time on the taxiway after landing could be due to congestion on the taxiway or time spent waiting for a gate to become available. In addition to queuing for the runway, excess departure delays and taxi-out time at hubs might also reflect such congestion as the "alleyways" between gates being blocked by other departing aircraft. All these factors are examples of limited airport capacity leading to congestion that would affect hub airlines more than non-hubs.

Our final set of specifications in Table 7 takes an alternative approach to estimating differences in travel time for departing and arriving flights. The results in Tables $3 \mathrm{~A}$ and $3 \mathrm{~B}$ suggest that flights originating at a hub have about 3 minutes longer excess travel times than flights arriving at hubs, no matter what the size of the 
Table 6-Decomposing Delays to Identify the Effects of Hubbing on Various Measures of Travel Time: 1995-2000

\begin{tabular}{|c|c|c|c|c|c|c|c|c|}
\hline \multirow{3}{*}{ Dependent variable: } & \multicolumn{2}{|r|}{$(1)$} & \multicolumn{2}{|r|}{$(2)$} & \multicolumn{2}{|r|}{ (3) } & \multicolumn{2}{|r|}{ (4) } \\
\hline & \multicolumn{2}{|c|}{ Departure delay } & \multicolumn{2}{|c|}{ Taxi-out time } & \multicolumn{2}{|c|}{ Flight time } & \multicolumn{2}{|c|}{ Taxi-in time } \\
\hline & Origin & Destination & Origin & Destination & Origin & Destination & Origin & Destination \\
\hline \multicolumn{9}{|l|}{ Airline hub size } \\
\hline 26-45 markets & $\begin{array}{c}1.73 \\
(0.26)\end{array}$ & $\begin{array}{c}-0.40 \\
(0.27)\end{array}$ & $\begin{array}{c}1.21 \\
(0.12)\end{array}$ & $\begin{array}{c}-0.59 \\
(0.11)\end{array}$ & $\begin{array}{c}-0.77 \\
(0.41)\end{array}$ & $\begin{array}{c}-0.38 \\
(0.41)\end{array}$ & $\begin{array}{c}0.05 \\
(0.07)\end{array}$ & $\begin{array}{c}0.41 \\
(0.07)\end{array}$ \\
\hline 46-70 markets & $\begin{array}{c}3.28 \\
(0.32)\end{array}$ & $\begin{array}{c}-0.27 \\
(0.32)\end{array}$ & $\begin{array}{c}1.58 \\
(0.15)\end{array}$ & $\begin{array}{c}-0.76 \\
(0.14)\end{array}$ & $\begin{array}{c}0.19 \\
(0.48)\end{array}$ & $\begin{array}{c}1.24 \\
(0.47)\end{array}$ & $\begin{array}{c}-0.30 \\
(0.08)\end{array}$ & $\begin{array}{c}1.38 \\
(0.08)\end{array}$ \\
\hline $71+$ markets & $\begin{array}{c}3.26 \\
(0.34)\end{array}$ & $\begin{array}{c}0.10 \\
(0.32)\end{array}$ & $\begin{array}{c}1.66 \\
(0.16)\end{array}$ & $\begin{array}{c}-0.78 \\
(0.16)\end{array}$ & $\begin{array}{c}0.13 \\
(0.47)\end{array}$ & $\begin{array}{c}1.21 \\
(0.48)\end{array}$ & $\begin{array}{c}-0.03 \\
(0.09)\end{array}$ & $\begin{array}{c}1.94 \\
(0.10)\end{array}$ \\
\hline \multicolumn{9}{|l|}{ Airport hub size } \\
\hline 26-45 markets & $\begin{array}{c}-2.31 \\
(0.25)\end{array}$ & $\begin{array}{c}-1.23 \\
(0.28)\end{array}$ & $\begin{array}{c}-1.34 \\
(0.11)\end{array}$ & $\begin{array}{c}-0.07 \\
(0.11)\end{array}$ & $\begin{array}{c}-0.30 \\
(0.26)\end{array}$ & $\begin{array}{c}-0.38 \\
(0.30)\end{array}$ & $\begin{array}{c}-0.05 \\
(0.05)\end{array}$ & $\begin{array}{c}-0.37 \\
(0.05)\end{array}$ \\
\hline 46-70 markets & $\begin{array}{c}-1.88 \\
(0.38)\end{array}$ & $\begin{array}{c}-0.54 \\
(0.39)\end{array}$ & $\begin{array}{c}-0.17 \\
(0.21)\end{array}$ & $\begin{array}{c}-0.004 \\
(0.19)\end{array}$ & $\begin{array}{c}-1.38 \\
(0.41)\end{array}$ & $\begin{array}{c}-0.03 \\
(0.40)\end{array}$ & $\begin{array}{c}0.04 \\
(0.08)\end{array}$ & $\begin{array}{c}-0.57 \\
(0.08)\end{array}$ \\
\hline $71+$ markets & $\begin{array}{c}-0.91 \\
(0.43)\end{array}$ & $\begin{array}{c}-0.03 \\
(0.46)\end{array}$ & $\begin{array}{c}0.03 \\
(0.23)\end{array}$ & $\begin{array}{c}-0.03 \\
(0.21)\end{array}$ & $\begin{array}{c}-1.28 \\
(0.49)\end{array}$ & $\begin{array}{c}-0.04 \\
(0.49)\end{array}$ & $\begin{array}{c}-0.21 \\
(0.10)\end{array}$ & $\begin{array}{r}-0.90 \\
(0.10)\end{array}$ \\
\hline Airport concentration & $\begin{array}{c}0.06 \\
(0.90)\end{array}$ & $\begin{array}{r}-0.98 \\
(1.00)\end{array}$ & $\begin{array}{c}-0.21 \\
(0.34)\end{array}$ & $\begin{array}{c}-0.47 \\
(0.38)\end{array}$ & $\begin{array}{c}-2.58 \\
(0.98)\end{array}$ & $\begin{array}{c}-2.95 \\
(1.02)\end{array}$ & $\begin{array}{c}-0.07 \\
(0.17)\end{array}$ & $\begin{array}{c}0.60 \\
(0.13)\end{array}$ \\
\hline$R^{2}$ & \multicolumn{2}{|r|}{0.17} & \multicolumn{2}{|r|}{0.57} & \multicolumn{2}{|r|}{0.30} & \multicolumn{2}{|r|}{0.64} \\
\hline
\end{tabular}

Notes: Robust standard errors are in parentheses. Regressions are based on the mean of the dependent and independent variables for each airline on every route for all months in every year $(\mathrm{N}=262,242$ airline-route-month/year cells). Equations also include indicator variables for year, month, airport, and airline, and various economic demand variables that are described in the paper.

hub. To examine these findings further, we rely on an identification approach similar to that in Borenstein (1991) in which he compares fares for flights on a given route arriving and departing from a carrier's own hub. We compute the difference in average travel time for departures versus arrivals on each route for each airline. These differences in travel time are regressed on variables for whether the origin airport was a hub, whether the flight was on an airline that hubbed at the origin airport, and the concentration at the origin airport. The coefficients on these variables can be interpreted as differences in the travel time for departures versus arrivals for each of the control variables.

The results in Table 7 show that the hub airline requires about 3 minutes longer travel time for flights originating at their own hub versus flights arriving at their hub, nearly exactly the same estimated difference between origin and destination travel time in Table 3B. The coefficients for the hub airline are little changed based on whether we use differences in total travel time or travel time above the minimum, or whether or not we include controls for route distance and direction. The latter controls are included to account for the possibility that the average hub is located in places where originating flights are systematically faster (or slower) due to natural weather or wind patterns. Differences in excess travel time for flights arriving or departing at hub airports (but not on the hub airline) and at concentrated airports are much smaller and not nearly as stable, suggesting that there are very few asymmetries in origin versus destination travel time when not traveling on the hub carrier.

\section{Conclusion}

Over the last 13 years, air traffic delays have grown considerably. From a policy perspective, it is important to distinguish between the two potential causes of delays: network benefits from hubbing, which lead hub carriers to accept higher equilibrium levels of delays, and congestion externalities, which cause higher delays for all carriers at an airport. Although we find evidence that congestion externalities lead to modest levels of air traffic delays, our results suggest that hubbing is the primary economic 
Table 7-Difference Between Time Required for Outbound and Return Flights ON ALL AIRLINE ROUTES

\begin{tabular}{|c|c|c|c|c|}
\hline \multirow[t]{2}{*}{ Dependent variable: } & \multicolumn{2}{|c|}{$\begin{array}{c}\text { Difference in } \\
\text { (travel time in } \\
\text { excess of } \\
\text { minimum feasible) } \\
\end{array}$} & \multicolumn{2}{|c|}{$\begin{array}{c}\text { Difference in } \\
\text { (total travel time) }\end{array}$} \\
\hline & (1) & (2) & (3) & (4) \\
\hline \multicolumn{5}{|l|}{ Airline hub size (at origination) } \\
\hline 26-45 markets & $\begin{array}{l}3.17 \\
(0.08)\end{array}$ & $\begin{array}{l}3.11 \\
(0.08)\end{array}$ & $\begin{array}{c}3.84 \\
(0.13)\end{array}$ & $\begin{array}{c}3.49 \\
(0.08)\end{array}$ \\
\hline 46-70 markets & $\begin{array}{c}3.04 \\
(0.08)\end{array}$ & $\begin{array}{l}3.08 \\
(0.07)\end{array}$ & $\begin{array}{c}2.52 \\
(0.12)\end{array}$ & $\begin{array}{c}2.72 \\
(0.07)\end{array}$ \\
\hline $71+$ markets & $\begin{array}{c}3.02 \\
(0.09)\end{array}$ & $\begin{array}{c}3.07 \\
(0.08)\end{array}$ & $\begin{array}{l}3.08 \\
(0.13)\end{array}$ & $\begin{array}{c}3.18 \\
(0.18)\end{array}$ \\
\hline \multicolumn{5}{|l|}{ Airport hub size (at origination) } \\
\hline $26-45$ markets & $\begin{array}{c}-0.02 \\
(0.07)\end{array}$ & $\begin{array}{c}0.15 \\
(0.07)\end{array}$ & $\begin{array}{c}-0.93 \\
(0.11)\end{array}$ & $\begin{array}{c}0.10 \\
(0.06)\end{array}$ \\
\hline 46-70 markets & $\begin{array}{c}0.42 \\
(0.09)\end{array}$ & $\begin{array}{c}0.05 \\
(0.08)\end{array}$ & $\begin{array}{c}0.42 \\
(0.13)\end{array}$ & $\begin{array}{r}-0.98 \\
(0.08)\end{array}$ \\
\hline $71+$ markets & $\begin{array}{c}0.23 \\
(0.09)\end{array}$ & $\begin{array}{c}-0.28 \\
(0.08)\end{array}$ & $\begin{array}{c}-0.40 \\
(0.12)\end{array}$ & $\begin{array}{l}-2.26 \\
(0.08)\end{array}$ \\
\hline Airport concentration (at origination) & $\begin{array}{c}-0.24 \\
(0.10)\end{array}$ & $\begin{array}{c}-0.37 \\
(0.10)\end{array}$ & $\begin{array}{c}0.66 \\
(0.14)\end{array}$ & $\begin{array}{c}0.52 \\
(0.10)\end{array}$ \\
\hline $\begin{array}{l}\text { Direction, time, and distance } \\
\text { interactions }\end{array}$ & No & Yes & No & Yes \\
\hline$R^{2}$ & 0.05 & 0.11 & 0.02 & 0.61 \\
\hline
\end{tabular}

Notes: Robust standard errors are in parentheses. Regressions are based on the difference between the mean time for outbound and return flights for each airline on every route with bi-directional service in a month $(\mathrm{N}=303,100$ airline-route-month/year cells). Direction, time, and distance interactions include a dummy variable for direction (north, south, east, west) interacted with a dummy variable for each month interacted with variables equal to distance between route airports and distance squared $(4 \times 12 \times 2=96$ additional variables).

contributor to air traffic congestion. Flights departing from hub airports require between 4 and 7 minutes of excess travel time, while flights arriving at a hub require 1.5 to 4.5 minutes of additional delay. However, nearly all of the delays associated with hubbing are incurred by the hub airline itself. Non-hub airlines operating at hub airports face minimal delays at all but the largest hubs. Within hubs, delays increase monotonically with the size of the hub and flights originating at the hub face greater delays than flights arriving at a hub. All of these findings are consistent with a model in which the hub carrier receives large network benefits that increase with the number of markets served from a hub. These interconnection benefits encourage the hub carrier to bunch its flights at hubbing times, even at the cost of additional delays to its own flights.

From a social perspective, our findings also suggest that the imposition of a Pigouvian tax or arbitrary caps on airport takeoffs and landings that do not account for the network benefits of hubbing might result in social losses. In the presence of hubbing, the optimal policy should not just minimize delays without considering interconnection benefits. Delays are not necessarily evidence of a socially inefficient outcome, but in many cases might reflect the optimal use of scarce runway capacity by hub airlines trying to provide consumers with a large variety of potential destinations and relatively short connection times. With a very high market share during peak hubbing times when most delays occur, dominant hub carriers already appear to internalize an appreciable portion of the congestion costs at their own hub airports. While hub carriers may impose a cost on nonhub airlines by crowding them out of certain flight times, a social planner who recognized the network benefits from hubbing might also 
choose a similar outcome. ${ }^{23}$ Also, not all of the costs of hubbing show up in delays. Hub airlines schedule longer layovers for their aircraft at their hubs, at a cost of having their planes sit idle, but reducing the extent of passenger delays. These costs, too, are internalized by hub carriers.

To some degree, our finding of a small congestion externality effect reflects the fact that the four airports most likely to suffer from itLaGuardia, JFK, Washington National, and Chicago O'Hare-already face FAA limits on the number of hourly flights at the airports. Indeed, our measured congestion externality effect increases when we exclude these airports from the estimation. In addition, in a wellpublicized policy shift, the FAA recently removed the hourly caps on service at LaGuardia, an airport that has a low concentration, no single dominant hub carrier, small capacity, and large local demand. Airlines immediately moved in to increase service. Shortly thereafter, LaGuardia accounted for about 25 percent of all delays of more than 15 minutes for the entire nation. This incident, along with our empirical results, suggests that congestion externalities are important at some airports, and would be more important were the FAA to remove the caps at any of the slot-constrained airports. Congestion pricing may be an appropriate solution for the inefficiency at these airports.

\section{REFERENCES}

-Arnott, Richard. "Unpriced Transport Congestion." Journal of Economic Theory, October 1979, 21(2), pp. 294-316.

Borenstein, Severin. "Hubs and High Fares: Dominance and Market Power in the U.S. Airline Industry." RAND Journal of Economics, Autumn 1989, 20(3), pp. 344-65. ."Airline Mergers, Airport Dominance, and Market Power." American Economic Re-

\footnotetext{
${ }^{23}$ These comments only relate to hub carrier choices relative to delays and do not measure the extent to which hub carriers have a high market share because they have successfully limited entry by other carriers. Debates over access to gates at the new airports in Denver and Pittsburgh suggest that market power over local passengers is an important consideration by airlines regarding their willingness to invest in additional capacity.
}

view, May 1990 (Papers and Proceedings), 80(2), pp. 400-04.

. "The Dominant-Firm Advantage in Multi-Product Industries: Evidence from the U.S. Airlines." Quarterly Journal of Economics, November 1991, 106(4), pp. 1237-66.

. "The Evolution of U.S. Airline Competition." Journal of Economic Perspectives, Spring 1992, 6(2), pp. 45-73.

-Borenstein, Severin and Netz, Janet. "Why Do All Flights Leave at 8 AM?: Competition and Departure-Time Differentiation in Airline Markets." International Journal of Industrial Organization, July 1999, 17(5), pp. 611-40.

Borenstein, Severin and Rose, Nancy. "Competition and Price Dispersion in the U.S. Airline Industry." Journal of Political Economy, August 1994, 103(4), pp. 653-83.

-Brueckner, Jan K. "Airport Congestion When Carriers Have Market Power." American Economic Review, December 2002, 92(5), pp. 1357-75.

Brueckner, Jan K.; Dyer, Nichola J. and Spiller, Pablo T. "Fare Determination in Airline Huband-Spoke Networks." RAND Journal of Economics, Autumn 1992, 23(3), pp. 30934.

Brueckner, Jan K. and Spiller, Pablo T. "Economies of Traffic Density in the Deregulated Airline Industry." Journal of Law and Economics, October 1994, 37(2), pp. 379-415.

Brueckner, Jan and Zhang, Yimin. "A Model of Scheduling in Airline Networks: How a Hub and Spoke System Affects Flight Frequency, Fares, and Welfare." Journal of Transportation Economics and Policy, May 2001, 35(2), pp. 195-222.

Carlin, Alan and Park, R. E. "Marginal Cost Pricing of Airport Runway Capacity." American Economic Review, June 1970, 60(3), pp. 310-19.

Caves, Douglas; Christensen, Lauritis and Tretheway, Michael. "Economies of Density versus Economies of Scale: Why Trunk and Local Service Airline Costs Differ." RAND Journal of Economics, Winter 1984, 15(4), pp. 47189.

Daniel, Joseph I. "Congestion Pricing and Capacity of Large Hub Airports: A Bottleneck Model with Stochastic Queues." Econometrica, March 1995, 63(2), pp. 327-70.

Daniel, Joseph I. and Pahwa, Munish. "Comparison of Three Empirical Models of Airport 
Pricing." Journal of Urban Economics, January 2000, 47(1), pp. 1-38.

Economides, Nicholas. "The Economics of Networks." International Journal of Industrial Organization, October 1996, 14(6), pp. 67399.

Encaoua, David; Moreaux, Michel and Perrot, Anne. "Compatability and Competition in Airlines: Demand Side Network Effects." International Journal of Industrial Organization, October 1996, 14(6), pp. 701-26.

Hendricks, Ken; Piccione, Michelle and Tan, Guofu. "The Economics of Hubs: The Case of Monopoly." Review of Economic Studies, January 1995, 62(1), pp. 83-99.

"Entry and Exit in Hub-Spoke Networks." RAND Journal of Economics, Summer 1997, 28(2), pp. 291-303.

Hergott, Matthew. "Airport Concentration and Market Power: An Events Study Approach." Review of Industrial Organization, December 1997, 12(5-6), pp. 793-800.

Kahn, Alfred. "The Competitive Consequences of Hub Dominance: A Case Study." Review of Industrial Organization, August 1993, 8(4), pp. 381-405.

Kim, E. Han and Singal, Vijay. "Mergers and Market Power: Evidence from the Airline Industry." American Economic Review, June 1993, 83(3), pp. 549-69.

McShan, Scott and Windle, Robert. "The Impli- cations of Hub-and-Spoke Routing for Airline Costs and Competitiveness." Logistics and Transportation Review, September 1989, 25(3), pp. 209-30.

Morrison, Steven. "Airline Mergers: A Longer View." Journal of Transport Economics and Policy, September 1996, 30(3), pp. 23750.

Morrison, Steven and Winston, Clifford. "Enhancing the Performance of the Deregulated Air Transportation System." Brookings $\mathrm{Pa}$ pers on Economic Activity, Microeconomics, 1989, Spec. Iss., pp. 61-123.

Saloner, Garth and Shepard, Andrea. "Adoption of Technologies with Network Effects: An Empirical Examination of the Adoption of Automated Teller Machines." RAND Journal of Economics, Autumn 1995, 26(3), pp. 479501.

Singal, Vijay. "Airline Mergers and Competition: An Integration of Stock and Product Price Effects." Journal of Business, April 1996, 69(2), pp. 233-68.

Vickrey, William S. "Congestion Theory and Transport Investment." American Economic Review, May 1969 (Papers and Proceedings), 59(2), pp. 251-60.

Zhang, Anming. "An Analysis of Fortress Hubs in Airline Networks." Journal of Transport Economics and Policy, September 1996, 30(3), pp. 293-307. 


\section{This article has been cited by:}

1. Hang Xiong, Diane Payne, Stephen Kinsella. 2016. Peer effects in the diffusion of innovations: Theory and simulation. Journal of Behavioral and Experimental Economics 63, 1-13. [CrossRef]

2. Jeffrey C. Brinkman. 2016. Congestion, agglomeration, and the structure of cities. Journal of Urban Economics 94, 13-31. [CrossRef]

3. Adams B. Steven, Amirhossein Alamdar Yazdi, Martin Dresner. 2016. Mergers and service quality in the airline industry: A silver lining for air travelers?. Transportation Research Part E: Logistics and Transportation Review 89, 1-13. [CrossRef]

4. Myung Suk Kim. 2016. Analysis of short-term forecasting for flight arrival time. Journal of Air Transport Management 52, 35-41. [CrossRef]

5. William E. Bendinelli, Humberto F.A.J. Bettini, Alessandro V.M. Oliveira. 2016. Airline delays, congestion internalization and non-price spillover effects of low cost carrier entry. Transportation Research Part A: Policy and Practice 85, 39-52. [CrossRef]

6. Paul Koster, Eric Pels, Erik Verhoef. 2016. The User Costs of Air Travel Delay Variability. Transportation Science 50, 120-131. [CrossRef]

7. Scott E. Atkinson, Kamalini Ramdas, Jonathan W. Williams. 2016. Robust Scheduling Practices in the U.S. Airline Industry: Costs, Returns, and Inefficiencies. Management Science . [CrossRef]

8. Xavier Fageda, Ricardo Flores-Fillol. 2016. How do airlines react to airport congestion? The role of networks. Regional Science and Urban Economics 56, 73-81. [CrossRef]

9. Harold L. VogelWings 47-117. [CrossRef]

10. Connan Snider, Jonathan W. Williams. 2015. Barriers to Entry in the Airline Industry: A Multidimensional Regression-Discontinuity Analysis of AIR-21. Review of Economics and Statistics 97, 1002-1022. [CrossRef]

11. Yulai Wan, Changmin Jiang, Anming Zhang. 2015. Airport congestion pricing and terminal investment: Effects of terminal congestion, passenger types, and concessions. Transportation Research Part B: Methodological 82, 91-113. [CrossRef]

12. Achim I. Czerny, Anming Zhang. 2015. Third-degree price discrimination in the presence of congestion externality. Canadian Journal of Economics/Revue canadienne d'économique 48:4, 1430-1455. [CrossRef]

13. Branko Bubalo, Alberto A. Gaggero. 2015. Low-cost carrier competition and airline service quality in Europe. Transport Policy 43, 23-31. [CrossRef]

14. Mahour Mellat-Parast, Davood Golmohammadi, Kathleen L. McFadden, Jason W. Miller. 2015. Linking business strategy to service failures and financial performance: Empirical evidence from the U.S. domestic airline industry. Journal of Operations Management 38, 14-24. [CrossRef]

15. Ater, Eugene Orlov. 2015. The Effect of the Internet on Performance and Quality: Evidence from the Airline Industry. Review of Economics and Statistics 97, 180-194. [CrossRef]

16. Lorenzo Mussone, Susan Grant-Muller, James Laird. 2015. Sensitivity analysis of traffic congestion costs in a network under a charging policy. Case Studies on Transport Policy 3, 44-54. [CrossRef]

17. James D. Reitzes, Brendan McVeigh, Nicholas Powers, Samuel Moy. 2015. Competitive Effects of Exchanges or Sales of Airport Landing Slots. Review of Industrial Organization 46, 95-125. [CrossRef]

18. Jeffrey T. Prince, Daniel H. Simon. 2015. Do Incumbents Improve Service Quality in Response to Entry? Evidence from Airlines' On-Time Performance. Management Science 61, 372-390. [CrossRef]

19. Naoshi Doi. 2014. Mutual influence across routes using a common airport: The case of the domestic market in Japan. Journal of Air Transport Management 40, 132-136. [CrossRef] 
20. Patrick Baumgarten, Robert Malina, Anne Lange. 2014. The impact of hubbing concentration on flight delays within airline networks: An empirical analysis of the US domestic market. Transportation Research Part E: Logistics and Transportation Review 66, 103-114. [CrossRef]

21. Miguel-Angel Alcobendas. 2014. Airline-airport agreements in the San Francisco Bay Area: Effects on airline behavior and congestion at airports. Economics of Transportation 3, 58-79. [CrossRef]

22. Hideki Fukui, Koki Nagata. 2014. Flight cancellation as a reaction to the tarmac delay rule: An unintended consequence of enhanced passenger protection. Economics of Transportation 3, 29-44. [CrossRef]

23. Achim I. Czerny, Anming Zhang. 2014. Airport peak-load pricing revisited: The case of peak and uniform tolls. Economics of Transportation 3, 90-101. [CrossRef]

24. Daniel Greenfield. 2014. Competition and service quality: New evidence from the airline industry. Economics of Transportation 3, 80-89. [CrossRef]

25. Philip G. Gayle, Chi-Yin Wu. 2014. On the Extent to which the Presence of Intermediate-stop(s) Air Travel Products Influences the Pricing of Nonstop Air Travel Products. Review of Network Economics 13. . [CrossRef]

26. Alexandre Jacquillat, Amedeo R. Odoni. 2013. Congestion Mitigation at John F. Kennedy International Airport in New York City. Transportation Research Record: Journal of the Transportation Research Board 2400, 28-36. [CrossRef]

27. Volodymyr Bilotkach, Xavier Fageda, Ricardo Flores-Fillol. 2013. Airline consolidation and the distribution of traffic between primary and secondary hubs. Regional Science and Urban Economics 43, 951-963. [CrossRef]

28. Hugo E. Silva, Erik T. Verhoef. 2013. Optimal pricing of flights and passengers at congested airports and the efficiency of atomistic charges. Journal of Public Economics 106, 1-13. [CrossRef]

29. Clifford Winston. 2013. On the Performance of the U.S. Transportation System: Caution Ahead. Journal of Economic Literature 51:3, 773-824. [Abstract] [View PDF article] [PDF with links]

30. Tim Hazledine, Rory Bunker. 2013. Airport size and travel time. Journal of Air Transport Management 32, 17-23. [CrossRef]

31. Andreas Polk, Volodymyr Bilotkach. 2013. The assessment of market power of hub airports. Transport Policy 29, 29-37. [CrossRef]

32. Gordon Phillips, Giorgo Sertsios. 2013. How Do Firm Financial Conditions Affect Product Quality and Pricing?. Management Science 59, 1764-1782. [CrossRef]

33. Mark Hansen, Bo ZouAirport Operational Performance and Its Impact on Airline Cost 119-143. [CrossRef]

34. Achim I. Czerny. 2013. Public versus private airport behavior when concession revenues exist. Economics of Transportation 2, 38-46. [CrossRef]

35. Pablo Fleurquin, José J. Ramasco, Victor M. Eguiluz. 2013. Systemic delay propagation in the US airport network. Scientific Reports 3. . [CrossRef]

36. Federico Ciliberto, Carola Schenone. 2012. Are the bankrupt skies the friendliest?. Journal of Corporate Finance 18, 1217-1231. [CrossRef]

37. Anming Zhang, Achim I. Czerny. 2012. Airports and airlines economics and policy: An interpretive review of recent research. Economics of Transportation 1, 15-34. [CrossRef]

38. Prem Swaroop, Bo Zou, Michael O. Ball, Mark Hansen. 2012. Do more US airports need slot controls? A welfare based approach to determine slot levels. Transportation Research Part B: Methodological 46, 1239-1259. [CrossRef] 
39. Bo Zou, Mark Hansen. 2012. Impact of operational performance on air carrier cost structure: Evidence from US airlines. Transportation Research Part E: Logistics and Transportation Review 48, 1032-1048. [CrossRef]

40. Itai Ater. 2012. Internalization of congestion at US hub airports. Journal of Urban Economics 72, 196-209. [CrossRef]

41. Adams B. Steven, Yan Dong, Martin Dresner. 2012. Linkages between customer service, customer satisfaction and performance in the airline industry: Investigation of non-linearities and moderating effects. Transportation Research Part E: Logistics and Transportation Review 48, 743-754. [CrossRef]

42. Vinayak Deshpande, Mazhar Arıkan. 2012. The Impact of Airline Flight Schedules on Flight Delays. Manufacturing \& Service Operations Management 14, 423-440. [CrossRef]

43. Rodrigo Britto, Martin Dresner, Augusto Voltes. 2012. The impact of flight delays on passenger demand and societal welfare. Transportation Research Part E: Logistics and Transportation Review 48, 460-469. [CrossRef]

44. Milind Sohoni, Yu-Ching Lee, Diego Klabjan. 2011. Robust Airline Scheduling Under Block-Time Uncertainty. Transportation Science 45, 451-464. [CrossRef]

45. Achim I. Czerny, Anming Zhang. 2011. Airport congestion pricing and passenger types. Transportation Research Part B: Methodological 45, 595-604. [CrossRef]

46. Joseph I. Daniel. 2011. Congestion pricing of Canadian airports. Canadian Journal of Economics/Revue canadienne d'économique 44:10.1111/caje.2011.44.issue-1, 290-324. [CrossRef]

47. Andrew C. L. Yuen, Anming Zhang. 2011. AIRPORT CONGESTION PRICING AND ITS WELFARE IMPLICATIONS: THE CASE OF VARIABLE PASSENGER TIME COSTS. Pacific Economic Review 16:10.1111/paer.2011.16.issue-1, 83-102. [CrossRef]

48. John A. Bishop, Nicholas G. Rupp, Buhong Zheng. 2011. Flight Delays and Passenger Preferences: An Axiomatic Approach. Southern Economic Journal 77, 543-556. [CrossRef]

49. Silke J. Forbes, Mara Lederman. 2010. Does vertical integration affect firm performance? Evidence from the airline industry. The RAND Journal of Economics 41:10.1111/rand.2010.41.issue-4, 765-790. [CrossRef]

50. Ahmed Hassan, Khaled Abdelghany, Ahmed Abdelghany. 2010. Modeling Framework for Evaluating Sensitivity of Airline Schedules to Airport Congestion Pricing. Transportation Research Record: Journal of the Transportation Research Board 2177, 33-40. [CrossRef]

51. Samir Elhedhli, Huyu Wu. 2010. A Lagrangean Heuristic for Hub-and-Spoke System Design with Capacity Selection and Congestion. INFORMS Journal on Computing 22, 282-296. [CrossRef]

52. Satyam Mukherjee, Neelima Gupte, Gautam Mukherjee. 2010. Statistical characterizers of transport in communication networks. Physical Review E 81. . [CrossRef]

53. Hideki Fukui. 2010. An empirical analysis of airport slot trading in the United States. Transportation Research Part B: Methodological 44, 330-357. [CrossRef]

54. Georgina Santos, Maël Robin. 2010. Determinants of delays at European airports. Transportation Research Part B: Methodological 44, 392-403. [CrossRef]

55. Ricardo Flores-Fillol. 2010. Congested hubs. Transportation Research Part B: Methodological 44, 358-370. [CrossRef]

56. Forbes Silke Januszewski, Lederman Mara. 2009. Adaptation and Vertical Integration in the Airline Industry. American Economic Review 99:5, 1831-1849. [Abstract] [View PDF article] [PDF with links]

57. Dipasis Bhadra. 2009. You (expect to) get what you pay for: A system approach to delay, fare, and complaints\#. Transportation Research Part A: Policy and Practice 43, 829-843. [CrossRef] 
58. Juan Carlos Martín, M. Pilar Socorro. 2009. A new era for airport regulators through capacity investments. Transportation Research Part A: Policy and Practice 43, 618-625. [CrossRef]

59. Joseph I. Daniel, Katherine Thomas Harback. 2009. Pricing the major US hub airports. Journal of Urban Economics 66, 33-56. [CrossRef]

60. Mark D. Moore. 2009. Distributed Aviation Concepts and Technologies. SAE International Journal of Aerospace 1, 714-731. [CrossRef]

61. J ISHII, S JUN, K VANDENDER. 2009. Air travel choices in multi-airport markets\#. Journal of Urban Economics 65, 216-227. [CrossRef]

62. N RUPP. 2009. Do carriers internalize congestion costs? Empirical evidence on the internalization question. Journal of Urban Economics 65, 24-37. [CrossRef]

63. Edward R. Bruning, Michael Y. Hu, Wei (Andrew) Hao. 2009. Cross-national segmentation: An application to the NAFTA airline passenger market. European Journal of Marketing 43, 1498-1522. [CrossRef]

64. Austan Goolsbee, Chad Syverson. 2008. How do Incumbents Respond to the Threat of Entry? Evidence from the Major Airlines *. Quarterly Journal of Economics 123:10.1162/ qjec.2008.123.issue-4, 1611-1633. [CrossRef]

65. Jan K. Brueckner, Kurt Van Dender. 2008. Atomistic congestion tolls at concentrated airports? Seeking a unified view in the internalization debate. Journal of Urban Economics 64, 288-295. [CrossRef]

66. Satyam Mukherjee, Neelima Gupte. 2008. Message transfer in a communication network. Pramana 70, 1109-1116. [CrossRef]

67. Satyam Mukherjee, Neelima Gupte. 2008. Gradient mechanism in a communication network. Physical Review E 77. . [CrossRef]

68. Joseph I. Daniel, Katherine Thomas Harback. 2008. (When) Do hub airlines internalize their selfimposed congestion delays?. Journal of Urban Economics 63, 583-612. [CrossRef]

69. Steven A. Morrison, Clifford Winston. 2008. The effect of FAA expenditures on air travel delays. Journal of Urban Economics 63, 669-678. [CrossRef]

70. K VANDENDER. 2007. Determinants of fares and operating revenues at US airports\#. Journal of Urban Economics 62, 317-336. [CrossRef]

71. Michael Keen, Jon Strand. 2007. Indirect Taxes on International Aviation. Fiscal Studies 28:10.1111/ fisc.2007.28.issue-1, 1-41. [CrossRef]

72. NICHOLAS G. RUPP, GEORGE M. HOLMES. 2006. An Investigation into the Determinants of Flight Cancellations. Economica 73:10.1111/ecca.2006.73.issue-292, 749-783. [CrossRef]

73. A ZHANG, Y ZHANG. 2006. Airport capacity and congestion when carriers have market power. Journal of Urban Economics 60, 229-247. [CrossRef]

74. Jon Strand, Michael Keen. 2006. Indirect Taxeson International Aviation. IMF Working Papers 06, 1. [CrossRef]

75. Paul L. Joskow. 2005. Regulation and Deregulation after 25 Years: Lessons Learned for Research in Industrial Organization. Review of Industrial Organization 26, 169-193. [CrossRef]

76. Kenneth Button. 2005. A simple analysis of the rent seeking of airlines, airports and politicians. Transport Policy 12, 47-56. [CrossRef] 